\title{
New insights on secondary minerals from Italian sulfuric acid caves
}

\author{
Ilenia M. D’Angeli ${ }^{1 *}$, Cristina Carbone ${ }^{2}$, Maria Nagostinis ${ }^{1}$, Mario Parise ${ }^{3}$, Marco Vattano ${ }^{4}$, \\ Giuliana Madonia ${ }^{4}$, and Jo De Waele ${ }^{1}$
}

${ }^{1}$ Department of Biological, Geological and Environmental Sciences, University of Bologna, Via Zamboni 67, 40126 Bologna, Italy

${ }^{2}$ DISTAV, Department of Geological, Environmental and Biological Sciences, University of Genoa, Corso Europa 26, 16132 Genova, Italy

${ }^{3}$ Department of Geological and Environmental Sciences, University of Bari Aldo Moro, Piazza Umberto I 1, 70121 Bari, Italy

${ }^{4}$ Department of Earth and Marine Sciences, University of Palermo, Via Archirafi 22, 90123 Palermo, Italy

\begin{abstract}
Sulfuric acid minerals are important clues to identify the speleogenetic phases of hypogene caves. Italy hosts $\sim 25 \%$ of the known worldwide sulfuric acid speleogenetic (SAS) systems, including the famous well-studied Frasassi, Monte Cucco, and Acquasanta Terme caves. Nevertheless, other underground environments have been analyzed, and interesting mineralogical assemblages were found associated with peculiar geomorphological features such as cupolas, replacement pockets, feeders, sulfuric notches, and sub-horizontal levels. In this paper, we focused on 15 cave systems located along the Apennine Chain, in Apulia, in Sicily, and in Sardinia, where copious SAS minerals were observed. Some of the studied systems (e.g., Porretta Terme, Capo Palinuro, Cassano allo Ionio, Cerchiara di Calabria, Santa Cesarea Terme) are still active, and mainly used as spas for human treatments. The most interesting and diversified mineralogical associations have been documented in Monte Cucco (Umbria) and Cavallone-Bove (Abruzzo) caves, in which the common gypsum is associated with alunite-jarosite minerals, but also with baryte, celestine, fluorite, and authigenic rutile-ilmenite-titanite. In addition, the core of alunite and jarosite, from these two systems, results enriched in $\mathrm{PO}_{4}{ }^{3-}$, clearly suggesting hypogene hydrothermal origin. Santa Cesarea Terme, Capo Palinuro, and Acqua Mintina caves show important native sulfur deposits, which abundantly cover walls, ceilings, and speleothems. Abundant copiapite, pickeringite, tamarugite, hexahydrate assemblages have been observed in the Calabrian systems; their association with pyrite and hematite would suggest they formed in very acidic conditions with $\mathrm{pH}$ ranging between 0 and 4 .
\end{abstract}

Keywords: $\quad$ hypogene, rising waters, Apennine Chain, mineralogy, cave sulfates

Received 11 January 2018; Revised 2 March 2018; Accepted 24 May 2018

Citation: D'Angeli I.M., Carbone C., Nagostinis M., Parise M., Vattano M., Madonia G. and De Waele J., 2018. New insights on secondary minerals from Italian sulfuric acid caves. International Journal of Speleology, 47 (3), 271-291. Tampa, FL (USA) ISSN 0392-6672 https://doi.org/10.5038/1827-806X.47.3.2175

\section{INTRODUCTION}

Italy hosts a wide variety of karstic rocks, such as carbonates (limestone, dolostone, conglomerate), evaporites (gypsum, anhydrite, and halite) and quartzites, in which important epigenic (due to the flow of shallow meteoric waters) or hypogenic (produced by ascending deep-seated waters or by aggressive solutions formed at depth below the surface) cave systems can develop (Palmer, 2007, 2011). Recently, the definition of hypogene processes has been rearranged, as cave speleogenesis related to "the formation of solution-enlarged permeability structures (void-conduit systems) by upwelling fluids that recharge the cavernous zone from hydrostratigraphically lower units, where fluids originate from distant or deep sources, independent of recharge from the overlying or immediately adjacent surface" (Klimchouk, 2017 p.3).

Upwelling fluids, along the pathway, are normally subjected to changes in pressure and temperature, causing continuous disequilibrium conditions, triggering mineral reactions and formation of macroporosity. The combination of variable conditions result in diverse genetic types with typical voidconduit patterns (Klimchouk, 2007, 2017). A genetic subdivision has been created in accordance with the dissolutive chemistry involved in cave speleogenesis, and the principal hypogenic karst types are: sulfuric acid (SAS), hydrothermal, mixing-corrosion, and evaporite-dissolution (Klimchouk, 2017). 
Here we focus on sulfuric acid speleogenetic (SAS) caves, which represent interesting systems characterized by peculiar geomorphological features due to rising flows (Palmer \& Palmer, 2000; Audra, 2008; Klimchouk, 2009; Palmer, 2013; De Waele et al., 2016), secondary mineral deposits (Polyak \& Provencio, 2001; Onac et al., 2009; Onac \& Forti, 2011; Audra et al., 2015), and peculiar biosignatures such as stream biofilms, vermiculations, moonmilk deposits, and snottites (Summers Engel et al., 2004; Macalady et al., 2006; D’Angeli et al., 2017b). They can evolve both in confined (under pressure) and unconfined settings (Klimchouk, 2005, 2009). Their main features are linked to ascending acidic waters, that gain their aggressiveness from deep-seated sources (Hill, 1990), such as: oxidation of magmatic gases $\left(\mathrm{H}_{2} \mathrm{~S}\right.$ and $\left.\mathrm{SO}_{2}\right)$, assimilatory-dissimilatory $\left(60-80^{\circ} \mathrm{C}\right)$ and $/$ or thermochemical $\left(100-180^{\circ} \mathrm{C}\right)$ sulfate-reduction (Canfield, 2001; Machel, 2001) of hydrocarbon and evaporite layers, reduction of marine waters involved in deep circulation flows, and/or reduction of sulfide ore deposits through abiotic and/or microbially-mediated actions (Audra et al., 2015).

The most important mechanism of the sulfuric acid process, firstly demonstrated by Egemeier (1981), is the oxidation of $\mathrm{H}_{2} \mathrm{~S}$ into $\mathrm{H}_{2} \mathrm{SO}_{4}$ (1).

$$
\mathrm{H}_{2} \mathrm{~S}+2 \mathrm{O}_{2} \rightarrow \mathrm{H}_{2} \mathrm{SO}_{4}
$$

This acid immediately reacts with the carbonate host-rock (2) producing replacement gypsum deposits and degassing $\mathrm{CO}_{2}$, further contributing in the dissolution processes.

$$
\begin{gathered}
\mathrm{CaCO}_{3}+\mathrm{SO}_{4}+2 \mathrm{H}^{+}+2 \mathrm{H}_{2} \mathrm{O} \rightarrow \\
\mathrm{CaSO}_{4} \cdot 2 \mathrm{H}_{2} \mathrm{O}+\mathrm{CO}_{2}+\mathrm{H}_{2} \mathrm{O}
\end{gathered}
$$

The interaction of $\mathrm{H}_{2} \mathrm{SO}_{4}$ with the insoluble deposits inside caves produces mineral assemblages belonging to the "speleogenetic by-products" (Polyak $\&$ Provencio, 2001), that have been clearly observed in some of the best-documented examples of fossil sulfuric acid caves, such as the case of Guadalupe Mountains (New Mexico, USA) (Hill, 1990; Jagnow et al., 2000; Palmer \& Palmer 2000), which evolved in areas characterized by extremely dry weather conditions, allowing the preservation of original sulfuric acid features also after exhumation (Palmer \& Palmer, 2000; Klimchouk et al., 2016). The speleogenetic by-products represent a consequence of: a) alteration of insoluble sediments (mostly aluminium phosphates and sulfates), b) replacement or alteration of carbonate rocks, and c) precipitation of dissolved species. They can mainly be divided (Polyak \& Provencio, 2001) into "primary" (direct results of $\mathrm{H}_{2} \mathrm{SO}_{4}$ ), and "secondary" by-products (due to the alteration of the primary minerals or late-stage remobilization of elements). In addition, aluminium phosphate and sulfate (APS) minerals, containing rare earth elements (REE) or radioactive ones, can constitute economic deposits, and may be used as a guide for metal-bearing ore deposits (Dill, 2001). $\mathrm{K}$-rich APS minerals belonging to the alunite group (alunite, natroalunite, and jarosite) are used to obtain relevant geochronological information, through $\mathrm{K} / \mathrm{Ar}$ or Ar/Ar dating (Polyak et al., 1998). From an overall point of view, speleogenetic by-products are essential clues to understand the environmental conditions of cave formation.

Italy hosts $\sim 25 \%$ of the known worldwide sulfuric acid caves (Galdenzi \& Menichetti, 1995; De Waele et al., 2014; D’Angeli et al., 2016), located especially along the Apennine Chain, in the southeast Apulian foreland, in Sicily and in Sardinia. Generally, the $\mathrm{H}_{2} \mathrm{~S}$ source is thought to be related to the deepseated upper Triassic evaporite unit called "Anidriti di Burano Formation (Fm.)" (Martinis \& Pieri, 1964; Ciarapica et al., 1986) cropping out in several regions of Italy including Emilia-Romagna, Tuscany, Latium, Umbria, Marche, and Apulia.

The findings of interesting mineralogical assemblages together with the presence of peculiar geomorphological features helped in the recognition of fossil SAS caves, and the aim of this paper is to revise the previous knowledge and put in light new insights into the origin of SAS minerals.

\section{GEOLOGICAL SETTING}

The geological history of Italy is very complex, and characterized by two main orogenic events (Doglioni $\&$ Flores, 1997). The Alps generated by a compression that started during the Eocene caused by the W-NW movement of the Adriatic Plate toward the Eurasian Plate. Whereas the Apennines evolved since the upper Eocene because of the slow subduction and movement of the Adriatic Plate toward the West. In Italy, sulfuric acid speleogenetic caves developed mainly along the Apennine Chain (asymmetric arc) divided into northern (E-Liguria, Emilia-Romagna, Tuscany, Marche), central (Latium, Umbria, Abruzzo, Molise), and southern (Campania, Basilicata, Calabria, Sicily), with three main forelands located in the Po Plain, Apulia, and southeastern Sicily. Generally, the stratigraphic succession is characterized by deep Caledonian-Hercynian rocks constituting the basement, covered by terrigenous clastic and peritidal sediments (upper Carnian), followed by shallow carbonate platforms "Dolomia Principale" (upper Triassic). Subsequently, tectonic movements controlled the geological structures, producing horsts and grabens and creating several sedimentary basins. During the Triassic, red beds called "Verrucano Fm." and evaporites known as the "Anidriti di Burano Fm." were deposited. In the terrains of Basilicata, Calabria, and Sicily deep water conditions allowed the deposition of cherts, limestone, and marls. Due to extensional tectonics, new basins were created during the Jurassic time, in which a series of new sediments were deposited: i) radiolarites and basinal limestones typical of oceanic domain (Liguria, W-Tuscany, southern Apennines), ii) pelagic and hemipelagic carbonates of basinal domain (southern Alps, and Sicily), and iii) shallow marine carbonates (Apulia, Friuli, Latium-Abruzzo, Campania-Lucania, Sicily platforms). The deposition of limestones of the "Maiolica Fm." occurred during the lower Cretaceous, 
while the "Scaglia Rossa Fm." limestones and Rudistic facies developed during the upper Cretaceous.

The above-described terrains were affected by compressive stresses due to the inversion of the relative motion between the Eurasian and Adriatic plates, that saw the later migration of thrust-belts.

Paleogene shallow water carbonates (Venetian foothills, Lessini) and Messinian evaporitic rocks "Gessoso-Solfifera Fm." deposited along the Apennine Chain, when the Mediterranean sea-level dropped drastically.

Italy is also characterized by volcanic activities both in the past (Ordovician, Pennsylvanian, lower Permian, Triassic) and in recent times (Vesuvius, Etna, Stromboli, Vulcano and in the Sicily channel). Petroleum and natural gas reserves have been found especially in the Po Plain, in the Adriatic Sea and along the Bradanic trough. Lignitic coals are very abundant (especially in Sardinia) with a sulfur content $>8 \%$, whereas ore deposits are limited except for the Paleozoic terrains of Sardinia. Travertines are abundantly present in the central Apennines, both as actively forming and as fossil Quaternary deposits (Taddeucci et al., 1992; Minissale, 2004).

The presence of abundant karstified rocks (Fig. 1), deep-seated Triassic evaporite deposits (at depths ranging between 600 and 2,500 m) (Martinis \& Pieri, 1964), hydrocarbon reservoirs, deep faults and thrust-belts, allows the widespread occurrence of rising acidic waters containing high concentration of $\mathrm{H}_{2} \mathrm{~S}, \mathrm{CO}_{2}$ and $\mathrm{CH}_{4}$, as testified by the presence of still-active and fossil hypogenic cave systems. Several examples of sulfuric acid speleogenetic cave systems are reported in Fig. 1.

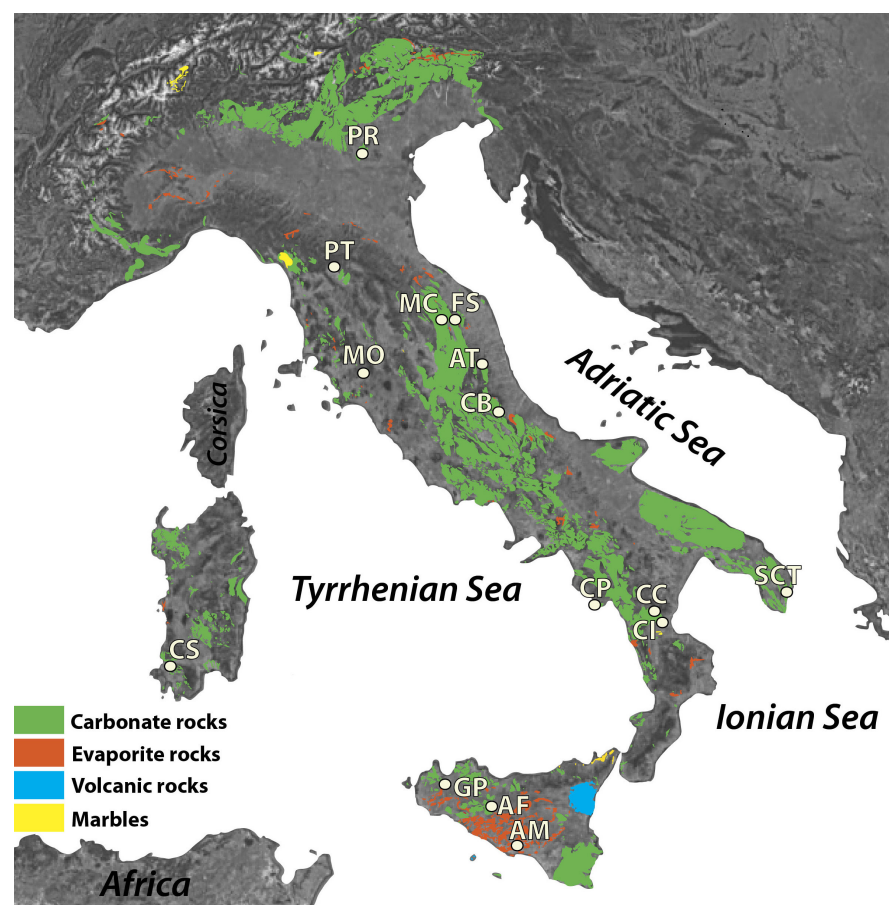

Fig. 1. Location of the sulfuric acid speleogenetic (SAS) caves studied: PR (Buso della Pisatela-Rana, Veneto), PT (Porretta Terme spa, EmiliaRomagna), MC (Monte Cucco, Umbria), FS (Frasassi, Marche), AT (Acquasanta Terme, Marche), MO (Montecchio, Tuscany), CB (CavalloneBove, Abruzzo), CP (Capo Palinuro, Campania), CC (Cerchiara di Calabria, Calabria), CI (Cassano allo Ionio, Calabria), SCT (Santa Cesarea Terme, Apulia), GP (Grotta che Parla, Sicily), AF (Acqua Fitusa, Sicily), AM (Acqua Mintina, Sicily), CS (Corona 'e sa Craba, Sardinia).
Buso della Pisatela-Rana (PR in Fig. 1) is located in the Venetian foreland, in the Faedo-Casaron Plateau. The area is characterized by shallow water deposits with terrigenous input (calcarenites, marls, claystones) belonging to the "Priabona Fm." (upper Eocene) and Castelgomberto calcarenites (Oligocene) rich in fossils. The genesis of the cave system is related to a combination of normal epigene speleogenesis and the localized oxidation of pyrite, which induced the subsequently production of $\mathrm{H}_{2} \mathrm{SO}_{4}$ (Tisato et al., 2012).

Porretta Terme spa (PT in Fig. 1), in the TuscanEmilian Apennines, opens in the "Arenarie di Suviana" (Oligocene) belonging to the "Porretta Terme Fm.". The artificial tunnels (realized in the $19^{\text {th }}$ century), similar to cave environments, host several sulfuric thermal springs and secondary mineral deposits.

Monte Cucco (MC in Fig. 1) and Frasassi (FS in Fig. 1) caves in the Umbro-Marche Apennines, developed in Jurassic carbonate rocks of the "Calcare Massiccio Fm." (Pialli et al., 1998). They represent the most studied SAS systems of Italy (Galdenzi \& Menichetti, 1995). They are huge cave systems (Monte Cucco is fossil, whereas Frasassi is still active) abundantly characterized by secondary minerals related to the interaction of the host rock with $\mathrm{H}_{2} \mathrm{SO}_{4}$.

Acquasanta Terme caves (AT in Fig. 1) open in the carbonate rocks belonging to the "Scaglia Rosata Fm." (Jurassic-Eocene), covered by Oligocene-Miocene marls and sandstone of the "Scaglia Cinerea Fm." (Menichetti, 2008; Galdenzi et al., 2010). Upwelling sulfuric thermal waters are still flowing through the gorge, and travertine terraces testify a long-lasting activity. Montecchio Cave (MO in Fig. 1), situated in southern Tuscany, evolved in massive Jurassic limestone of "Calcare Massiccio Fm.", and in cherty limestones of the "Calcare selcifero di Limano". It is composed of several sub-horizontal levels, the lower one hosting a still active sulfuric acid pool (Piccini et al., 2015).

Cavallone-Bove cave system (CB in Fig. 1), is located in the central Apennines, in the Majella Park (Abruzzo), and opens in fossiliferous marine limestones (upper Cretaceous). The two caves (Cavallone and Bove) were part of a larger system partially dismantled by surface erosion through formation of a deep gorge, and present evident signs of sulfuric acid speleogenetic processes, including an interesting association of minerals and typical geomorphological features. The Capo Palinuro (CP in Fig. 1) massif is located along the coast of Campania region (Tyrrhenian Sea) and is characterized by 32 submarine caves, completely or partially submerged (Canganella et al., 2007), developed in Jurassic marine limestones and dolostones. Only 13 caves show active sulfuric acid springs with elevated concentration of $\mathrm{H}_{2} \mathrm{~S}$ and temperature up to $25^{\circ} \mathrm{C}$ (Stüben et al., 1996). The most famous and studied cave is "Grotta Azzurra", in which the innermost part presents upwelling sulfidic waters.

Cerchiara di Calabria (CC in Fig. 1) and Cassano allo Ionio caves (CI in Fig. 1) are located in the southern Apennines and developed in upper Miocene 
biogenic calcarenites of the "Cerchiara Fm." (Selli, 1957) and Triassic dark-grey dolostones (Selli, 1962), respectively. The two areas are composed of wellramified caves both with sub-horizontal levels, and deep shafts carved by SAS processes. The lower levels, nowadays used as spa, present a still active flow of rising thermal waters. Santa Cesarea Terme Caves (SCT in Fig. 1), situated in the southeastern part of the Apulian foreland, are hosted in micritic limestones and dolostones belonging to the upper Cretaceous "Calcari d'Altamura Fm." (Azzaroli, 1967). The system is composed of four caves of moderate size, developed along the Adriatic coastline at present-day sea level (D'Angeli et al., 2017a). In these environments, the mixing of sulfuric acid and sea waters occurs, producing interesting morphologies due to different dissolution-corrosion processes.

Grotta che Parla Cave (GP in Fig. 1) opens in the NE sector of Montagna Grande, a relief located close to the Calatafimi village (Western Sicily). It is a small cavity $200 \mathrm{~m}$ long and $25 \mathrm{~m}$ deep, mainly oriented NW-SE. The cave develops on two levels, which mainly follow the bedding planes with a slope of $25^{\circ}$ toward the SE. The passages show cupolas, pillars, pendants, likely related to the sulfuric acid processes. Its entrance opens in an artificial scarp of a still active limestone quarry. The cave evolves in sequences of limestone and dolomitic limestones of "Inici Fm." (upper Jurassic). In this Formation a dense network of volcanic dikes filled by Jurassic deposits with $\mathrm{Fe}$ Mn oxides encrustations occurs (Martire et al., 2000; Basilone, 2012).

Acqua Fitusa Cave (AF, in Fig. 1), is placed in the eastern part of the Sicani Mountains, in San Giovanni in Gemini (Sicily). It opens in the breccia member of "Crisanti Fm." (upper Cretaceous), characterized by conglomerates and calcarenites with rudists and benthic foraminifera (Catalano et al., 2013). It represents a sulfuric water table cave (De Waele et al., 2016), nowadays disconnected from the actual spring.

Acqua Mintina Cave (AM in Fig. 1) is situated in the southern Sicily $\sim 7 \mathrm{~km}$ NW from Butera village (Caltanissetta province). It opens in the lowest layer of the "Calcare di base Fm." (Miocene) in contact with the underlying Tripoli marls (Lugli et al., 2016; Vattano et al., 2017). Above the "Calcare di Base Fm." there are selenitic layers belonging to the upper Gypsum Unit of the "Pasquasia Fm." (Manzi et al., 2009). Acqua Mintina is a $140 \mathrm{~m}$ long fossil cave and the conduit size decreases inland. Its walls are copiously covered by yellowish sulfur deposits, whereas on the floor it is possible to find inactive pools filled with selenitic gypsum crystals.

Corona 'e sa Craba Cave (CS in Fig. 1) is situated in the SW part of Sardinia, develops in quartzites (Sauro et al., 2014) produced by silicification processes that involved Cambrian sediments (Padalino et al., 1973). Corona 'e sa Craba is a relative large hydrothermal cave hosting an interesting association of secondary minerals (Sauro et al., 2014). As a matter of fact, the first visitors at the site were minerals collectors, searching for baryte crystals.

\section{METHODS}

We collected mineralogical samples from Porretta Terme (PT) thermal spa in Emilia-Romagna, Monte Cucco caves (La Grotta and Faggeto Tondo) in Umbria, Cavallone-Bove system in Abruzzo, Cassano allo Ionio and Cerchiara caves in Calabria, Santa Cesarea Terme caves in Apulia, Acqua Fitusa, Acqua Mintina and Grotta che Parla caves in Sicily. The mineralogical data from Buso della Pisatela-Rana (Veneto), Montecchio (Tuscany), Frasassi (Marche), Acquasanta Terme (Marche) and Corona 'e sa Craba (Sardinia) caves came from the literature (Table 1). In a few cases, we integrate our results with those reported in previous works.

Firstly, the samples were ground using agate mortar to obtain ultrafine powders. We analyzed 204 samples using the Philips PW3710 diffractometer (equipped with a Co tube working with the following characteristics: $\lambda=1.78901 \AA, 20 \mathrm{~mA}, 40 \mathrm{kV}, 3^{\circ}$ to $80^{\circ}$ $2 \theta$ with a step size of $0.02^{\circ}$, analysis time $1 \mathrm{sec}$ per point) and 44 samples, coated with carbon, have been observed using VEGA3-TESCAN type LMU Scanning Electron Microscope provided with a EDS detector (APOLLO XSDD, EDAX) at the University of Genoa.

We recorded 54 different minerals, most of them strictly related to sulfuric acid processes, and other minerals unrelated to the speleogenetic by-products (such as muscovite, kaolinite, and montmorillonite).

Table 1. List of the cave systems for which we used some mineralogical data from the literature.

\begin{tabular}{|c|c|c|c|}
\hline Cave systems & Location & References & Symbol \\
\hline Buso della Pisatela-Buso della Rana & VI, Veneto & $\begin{array}{c}\text { Tisato et al., 2012; } \\
\text { Fabiani, } 1915\end{array}$ & $\begin{array}{l}\mathrm{a} \\
\mathrm{b}\end{array}$ \\
\hline Monte Cucco & PG, Umbria & Forti et al., 1989 & $\mathrm{c}$ \\
\hline Frasassi & AN, Marche & $\begin{array}{l}\text { Caillère \& Hénin, 1963; } \\
\text { Millot, 1964; } \\
\text { Perna, 1973; } \\
\text { Bertolani et al., } 1976 ; \\
\text { Galdenzi, } 1990\end{array}$ & $\begin{array}{l}\mathrm{d} \\
\mathrm{e} \\
\mathrm{f} \\
\mathrm{g} \\
\mathrm{h}\end{array}$ \\
\hline Acquasanta Terme & AP, Marche & Galdenzi \& Menichetti, 1995 & $\mathrm{i}$ \\
\hline Montecchio & GR, Tuscany & Piccini et al., 2015 & $\mathrm{j}$ \\
\hline Capo Palinuro & SA, Campania & Forti \& Mocchiutti, 2004 & $\mathrm{k}$ \\
\hline Cassano allo Iono & $\mathrm{CO}$, Calabria & Catalano et al., 2014 & 1 \\
\hline Corona 'e sa Craba & CI, Sardinia & Sauro et al., 2014 & $\mathrm{~m}$ \\
\hline
\end{tabular}




\section{RESULTS}

All the caves reported in this paper host peculiar associations of speleogenetic by-products (Polyak $\&$ Provencio, 2001). The most common mineral is gypsum $\left[\mathrm{Ca}\left(\mathrm{SO}_{4}\right) \cdot 2 \mathrm{H}_{2} \mathrm{O}\right]$, abundantly present in all the investigated systems (Table 2). It can occur in different morphologies (Fig. 2), displaying chandelier structures (such as in Faggeto Tondo, Santa Cesarea Terme, and Acqua Mintina caves Fig. 2A-F-I), microcrystalline deposits (like in Cavallone-Bove and Calabrian caves Fig. 2B-C-D), stalactites (Santa Cesarea Terme Fig. 2E), white moonmilk deposits with a creamy appearance and radial crystals (Santa Cesarea Terme Fig. 2G-H). In some cases, gypsum is associated with native sulfur [S] deposits (Table 2), developed in small pockets (Faggeto Tondo Cave in Fig. 3A), on the walls and ceilings (Acquasanta Terme, Santa Cesarea Terme, and Acqua Mintina caves in Fig. 3B-C-F), and/ or covering gypsum speleothems as in Cala Fetente Cave (Fig. 3D-E), Capo Palinuro (Campania). In Acqua Mintina the external surface of the host rock is deeply weathered and replaced by a mineralogical assemblage of gypsum and celestine $\left[\mathrm{Sr}\left(\mathrm{SO}_{4}\right)\right]$, ultimately covered by a thin coating of organic matter with dark tones, visible on the lower part of Fig. $3 \mathrm{~F}$.

Table 2. List of the minerals found in the SAS systems of Italy; the apex letters (a-m) refer to the references reported in Table 1. The mineral names and formulas are reported according to the presently accepted IMA list of minerals (http://nrmima.nrm.se//imalist.htm), and sorted following the order: native elements, halides, sulfides, oxides, hydroxides, carbonates, sulfates, phosphates, silicates. Caves labels as Figure 1.

\begin{tabular}{|c|c|c|c|c|c|c|c|c|c|c|c|c|c|c|c|c|c|}
\hline Name & Formula & Compounds & $\stackrel{\alpha}{\alpha}$ & $\dot{\Delta}$ & ర్ & 住 & 安 & 일 & 畕 & $\theta$ & O & v & 桼 & 원 & 焉 & 这 & z \\
\hline Sulfur & $\mathrm{S}$ & Native element & $\mathrm{x}^{\mathrm{a}}$ & $\mathrm{x}$ & $\mathrm{x}$ & & $\mathrm{x}^{\mathrm{i}}$ & & & $\mathrm{x}^{\mathrm{k}}$ & & $\mathrm{x}$ & $\mathrm{x}$ & & & $\mathrm{x}$ & \\
\hline Fluorite & $\mathrm{CaF}_{2}$ & Halide & & & $\mathrm{x}$ & & & & & & & & & & & & \\
\hline Cinnabar & HgS & Sulfide & & & & & & & & & & & & & & & $\mathrm{x}^{\mathrm{m}}$ \\
\hline Pyrite & $\mathrm{FeS}_{2}$ & Sulfide & $\mathrm{x}^{\mathrm{a}}$ & & & & & & & & & $\mathrm{x}^{1}$ & & & & & \\
\hline Pyrolusite & $\mathrm{MnO}_{2}$ & Oxide & & & & & & & & & & & & & & & $\mathrm{x}^{\mathrm{m}}$ \\
\hline Rutile & $\mathrm{TiO}_{2}$ & Oxide & & & $\mathrm{x}$ & & & & $\mathrm{x}$ & & & $\mathrm{x}^{1}$ & & & & & \\
\hline Hematite & $\mathrm{Fe}_{2} \mathrm{O}_{3}$ & Oxide & $\mathrm{x}^{\mathrm{a}}$ & & & & & $x^{j}$ & & & & $\mathrm{x}^{1}$ & & & & & $\mathrm{x}^{\mathrm{m}}$ \\
\hline Ilmenite & $\mathrm{Fe}^{2+} \mathrm{Ti}^{4+} \mathrm{O}_{3}$ & Oxide & & & & & & & $\mathrm{x}$ & & & & & & & & \\
\hline Magnetite & $\mathrm{Fe}^{2+} \mathrm{Fe}^{3+}{ }_{2} \mathrm{O}_{4}$ & Oxide & & & $\mathrm{x}$ & & & & $\mathrm{x}$ & & & & & & & & \\
\hline Goethite & $\mathrm{FeO}(\mathrm{OH})$ & Hydroxide & $\mathrm{x}^{\mathrm{a}}$ & & $\mathrm{x}$ & & & $x^{j}$ & $\mathrm{x}$ & & & $\mathrm{x}^{1}$ & & & & & $\mathrm{x}^{\mathrm{m}}$ \\
\hline Böhmite & $\mathrm{AlO}(\mathrm{OH})$ & Hydroxide & & & & & & $x^{j}$ & & & & & & & & & \\
\hline Brucite & $\mathrm{Mn}(\mathrm{OH})_{2}$ & Hydroxide & & & & & & & $\mathrm{x}$ & & & $\mathrm{x}$ & & & & & \\
\hline Gibbsite & $\mathrm{Al}(\mathrm{OH})_{3}$ & Hydroxide & & & $\mathrm{x}$ & & & & $\mathrm{x}$ & & & & & & & & \\
\hline Todorokite & $\begin{array}{c}(\mathrm{Na}, \mathrm{Ca}, \mathrm{K}, \mathrm{Ba}, \mathrm{Sr})_{1-\mathrm{n}} \\
(\mathrm{Mn}, \mathrm{Mg}, \mathrm{Al})_{6} \mathrm{O}_{12} \cdot 3-4 \mathrm{H}_{2} \mathrm{O}\end{array}$ & Hydroxide & & & & & & & & & & & & & & & $\mathrm{x}^{\mathrm{m}}$ \\
\hline Calcite & $\mathrm{Ca}\left(\mathrm{CO}_{3}\right)$ & Carbonates & $\mathrm{x}^{\mathrm{a}, \mathrm{b}}$ & & $\mathrm{x}$ & & $x^{i}$ & $x^{j}$ & $\mathrm{x}$ & & $\mathrm{x}$ & $\mathrm{x}$ & & $\mathrm{x}$ & $\mathrm{x}$ & $\mathrm{x}$ & $\mathrm{x}^{\mathrm{m}}$ \\
\hline Aragonite & $\mathrm{Ca}\left(\mathrm{CO}_{3}\right)$ & Carbonates & & & & & $x^{i}$ & & & & & & & & & & $x^{m}$ \\
\hline Magnesite & $\mathrm{Mg}\left(\mathrm{CO}_{3}\right)$ & Carbonates & & & & & & & & & & $\mathrm{x}^{1}$ & & & & & \\
\hline Dolomite & $\mathrm{CaMg}\left(\mathrm{CO}_{3}\right)_{2}$ & Carbonates & $\mathrm{x}^{\mathrm{a}, \mathrm{b}}$ & & & & & & & & & $\mathrm{x}$ & $\mathrm{x}$ & $\mathrm{x}$ & & & $\mathrm{x}^{\mathrm{m}}$ \\
\hline Hydrotalcite & $\mathrm{Mg}_{6} \mathrm{Al}_{2}\left(\mathrm{CO}_{3}\right)(\mathrm{OH})_{16} \cdot 4 \mathrm{H}_{2} \mathrm{O}$ & Carbonates & & & $\mathrm{x}$ & & & & & & & & & & & & \\
\hline Thénardite & $\mathrm{Na}_{2}\left(\mathrm{SO}_{4}\right)$ & Sulfate & & & & & & & & & & & & & $\mathrm{x}$ & & \\
\hline Celestine & $\mathrm{Sr}\left(\mathrm{SO}_{4}\right)$ & Sulfate & $\mathrm{x}^{\mathrm{a}}$ & & $\mathrm{x}^{\mathrm{c}}$ & & & & & & & & & & & $\mathrm{x}$ & \\
\hline Baryte & $\mathrm{Ba}\left(\mathrm{SO}_{4}\right)$ & Sulfate & & & $\mathrm{x}$ & $x^{f}$ & & & & & & $x^{1}$ & & & & & $\mathrm{x}^{\mathrm{m}}$ \\
\hline Hexahydrite & $\mathrm{Mg}\left(\mathrm{SO}_{4}\right) \cdot 6 \mathrm{H}_{2} \mathrm{O}$ & Sulfate & & & & & & & & & & $\mathrm{x}$ & & & & $\mathrm{x}$ & \\
\hline Epsomite & $\mathrm{Mg}\left(\mathrm{SO}_{4}\right) \cdot 7 \mathrm{H}_{2} \mathrm{O}$ & Sulfate & & & & & & & & & & $\mathrm{x}$ & & & & $\mathrm{x}$ & \\
\hline Gypsum & $\mathrm{Ca}\left(\mathrm{SO}_{4}\right) \cdot 2 \mathrm{H}_{2} \mathrm{O}$ & Sulfate & $\mathrm{x}^{\mathrm{a}}$ & $\mathrm{x}$ & $\mathrm{x}$ & $\mathrm{x}^{\mathrm{h}}$ & $x^{i}$ & $x^{j}$ & $\mathrm{x}$ & $\mathrm{x}$ & $\mathrm{x}$ & $\mathrm{x}$ & $\mathrm{x}$ & $\mathrm{x}$ & $\mathrm{x}$ & $\mathrm{x}$ & $\mathrm{x}^{\mathrm{m}}$ \\
\hline Felsöbányaite & $\mathrm{Al}_{4}\left(\mathrm{SO}_{4}\right)(\mathrm{OH})_{10} \cdot 4 \mathrm{H}_{2} \mathrm{O}$ & Sulfate & & & & & & & & & & & & & & & $\mathrm{x}^{\mathrm{m}}$ \\
\hline Tamarugite & $\mathrm{NaAl}\left(\mathrm{SO}_{4}\right)_{2} \cdot 6 \mathrm{H}_{2} \mathrm{O}$ & Sulfate & & & & & & & & & & $\mathrm{x}$ & & & & & \\
\hline Alum-(K) & $\mathrm{KAl}\left(\mathrm{SO}_{4}\right)_{2} \cdot 12 \mathrm{H}_{2} \mathrm{O}$ & Sulfate & & & & & & & & & & & & & & $\mathrm{x}$ & \\
\hline Pickeringite & $\mathrm{MgAl}_{2}\left(\mathrm{SO}_{4}\right)_{4} \cdot 22 \mathrm{H}_{2} \mathrm{O}$ & Sulfate & & & & & & & & & & $\mathrm{x}$ & & & & & \\
\hline Natroalunite & $\mathrm{NaAl}_{3}\left(\mathrm{SO}_{4}\right)_{2}(\mathrm{OH})_{6}$ & Sulfate & & & & & & & $\mathrm{x}$ & & & & & & & & $x^{m}$ \\
\hline Alunite & $\mathrm{KAl}_{3}\left(\mathrm{SO}_{4}\right)_{2}(\mathrm{OH})_{6}$ & Sulfate & & & $\mathrm{x}$ & & & $x^{j}$ & $\mathrm{x}$ & & & & & & & $\mathrm{x}$ & $x^{m}$ \\
\hline Walthierite & $\mathrm{Ba}_{0.5} \mathrm{Al}_{3}\left(\mathrm{SO}_{4}\right)_{2}(\mathrm{OH})_{6}$ & Sulfate & & & & & & & & & & & & & & & $\mathrm{x}^{\mathrm{m}}$ \\
\hline Tschermigite & $\left(\mathrm{NH}_{4}\right) \mathrm{Al}\left(\mathrm{SO}_{4}\right)_{2} \cdot 12 \mathrm{H}_{2} \mathrm{O}$ & Sulfate & & & & & & & & & $\mathrm{x}$ & & & & & $\mathrm{x}$ & \\
\hline Eugsterite & $\mathrm{Na}_{4} \mathrm{Ca}\left(\mathrm{SO}_{4}\right)_{3} \cdot 2 \mathrm{H}_{2} \mathrm{O}$ & Sulfate & & & & & & & & & & & & & $\mathrm{x}$ & & \\
\hline Metavoltine & $\mathrm{K}_{2} \mathrm{Na}_{6} \mathrm{Fe}^{2+} \mathrm{Fe}^{3+}{ }_{6} \mathrm{O}_{2}\left(\mathrm{SO}_{4}\right)_{12} \cdot 18 \mathrm{H}_{2} \mathrm{O}$ & Sulfate & & & & & & & & & & & & & & $\mathrm{x}$ & \\
\hline Jarosite & $\mathrm{KFe}^{3+}{ }_{3}\left(\mathrm{SO}_{4}\right)_{2}(\mathrm{OH})_{6}$ & Sulfate & & $\mathrm{x}$ & $\mathrm{x}$ & $\mathrm{x}^{\mathrm{d}, \mathrm{e}, \mathrm{g}}$ & & $x^{j}$ & $\mathrm{x}$ & & & $\mathrm{x}$ & $\mathrm{x}$ & & & $\mathrm{x}$ & \\
\hline Copiapite & $\mathrm{Fe}^{2+} \mathrm{Fe}^{3+}{ }_{4}\left(\mathrm{SO}_{4}\right)_{6}(\mathrm{OH})_{2} \cdot 2 \mathrm{OH}_{2} \mathrm{O}$ & Sulfate & & & & & & & & & $\mathrm{x}$ & & & & & & \\
\hline Berlinite? & $\mathrm{Al}\left(\mathrm{PO}_{4}\right)$ & Phosphate & & & & & & & & & & & & & & & $\mathrm{x}^{\mathrm{m}}$ \\
\hline Fluorapatite & $\mathrm{Ca}_{5}\left(\mathrm{PO}_{4}\right)_{3} \mathrm{~F}$ & Phosphate & & & $\mathrm{x}$ & & & & & & & & & & & & \\
\hline
\end{tabular}




\begin{tabular}{|c|c|c|c|c|c|c|c|c|c|c|c|c|c|c|}
\hline Hydroxylapatite & $\mathrm{Ca}_{5}\left(\mathrm{PO}_{4}\right)_{3}(\mathrm{OH})$ & Phosphate & & $\mathrm{x}$ & & & $\mathrm{x}$ & & & & & & & $\mathrm{x}^{\mathrm{m}}$ \\
\hline Leucophosphite & $\mathrm{KFe}^{3+}{ }_{2}\left(\mathrm{PO}_{4}\right)_{2}(\mathrm{OH}) \cdot 2 \mathrm{H}_{2} \mathrm{O}$ & Phosphate & & $\mathrm{x}$ & & & & & & & & & & \\
\hline Vashegyite & $\mathrm{Al}_{11}\left(\mathrm{PO}_{4}\right)_{9}(\mathrm{OH})_{6} \cdot 38 \mathrm{H}_{2} \mathrm{O}$ & Phosphate & & & & & & & & & & & & $\mathrm{x}^{\mathrm{m}}$ \\
\hline Robertsite & $\mathrm{Ca}_{2} \mathrm{Mn}^{3+}{ }_{3} \mathrm{O}_{2}\left(\mathrm{PO}_{4}\right)_{3} \cdot 3 \mathrm{H}_{2} \mathrm{O}$ & Phosphate & & & & & & & & & & & & $\mathrm{x}^{\mathrm{m}}$ \\
\hline Spheniscidite & $\left(\mathrm{NH}_{4}\right) \mathrm{Fe}^{3+}{ }_{2}\left(\mathrm{PO}_{4}\right)_{2}(\mathrm{OH}) \cdot 2 \mathrm{H}_{2} \mathrm{O}$ & Phosphate & & & & & & & & & & & & $\mathrm{x}^{\mathrm{m}}$ \\
\hline Taranakite & $\mathrm{K}_{3} \mathrm{Al}_{5}\left(\mathrm{PO}_{3} \mathrm{OH}\right)_{6}\left(\mathrm{PO}_{4}\right)_{2} \cdot 18 \mathrm{H}_{2} \mathrm{O}$ & Phosphate & & & & & & & & & & & & $\mathrm{x}^{\mathrm{m}}$ \\
\hline Goyazite & $\mathrm{SrAl}_{3}\left(\mathrm{PO}_{4}\right)\left(\mathrm{PO}_{3} \mathrm{OH}\right)(\mathrm{OH})_{6}$ & Phosphate & & $\mathrm{x}$ & & & & & & & & & & \\
\hline Quartz & $\mathrm{SiO}_{2}$ & Silicate & $\mathrm{x}$ & $\mathrm{x}$ & & $x^{j}$ & $\mathrm{x}$ & $\mathrm{x}$ & $\mathrm{x}$ & $\mathrm{x}$ & & $\mathrm{x}$ & $\mathrm{x}$ & $\mathrm{x}^{\mathrm{m}}$ \\
\hline Opal & $\mathrm{SiO}_{2} \cdot \mathrm{nH}_{2} \mathrm{O}$ & Silicate & & & $\mathrm{X}^{\mathrm{d}, \mathrm{e}, \mathrm{g}}$ & & & & & & & & & \\
\hline Titanite & $\mathrm{CaTi}\left(\mathrm{SiO}_{4}\right) \mathrm{O}$ & Silicate & & $\mathrm{x}$ & & & & & & & & & & \\
\hline Muscovite & $\mathrm{KAl}_{2}\left(\mathrm{Si}_{3} \mathrm{Al}\right) \mathrm{O}_{10}(\mathrm{OH})_{2}$ & Silicate & $\mathrm{x}$ & & & & $\mathrm{x}$ & & $\mathrm{x}$ & & & & & \\
\hline Kaolinite & $\mathrm{Al}_{2} \mathrm{Si}_{2} \mathrm{O}_{5}(\mathrm{OH})_{4}$ & Silicate & & $\mathrm{x}$ & & $x^{j}$ & $\mathrm{x}$ & & & & & & & \\
\hline Greenalite & $\left(\mathrm{Fe}^{2+}, \mathrm{Fe}^{3+}\right)_{2-3} \mathrm{Si}_{2} \mathrm{O}_{5}(\mathrm{OH})_{4}$ & Silicate & & & & & & & & & $\mathrm{x}$ & & & \\
\hline Lizardite & $\mathrm{Mg}_{3} \mathrm{Si}_{2} \mathrm{O}_{5}(\mathrm{OH})_{4}$ & Silicate & & & & & & & & & & & & $\mathrm{x}^{\mathrm{m}}$ \\
\hline Montmorillonite & $\begin{array}{c}(\mathrm{Na}, \mathrm{Ca})_{0.33}\left(\mathrm{Al}, \mathrm{Mg}_{2}\right)_{2} \mathrm{Si}_{4} \mathrm{O}_{10} \\
(\mathrm{OH})_{2} \cdot \mathrm{nH}_{2} \mathrm{O}\end{array}$ & Silicate & & & & & & & $\mathrm{x}$ & & & & & \\
\hline Halloysite-10Å & $\mathrm{Al}_{2} \mathrm{Si}_{2} \mathrm{O}_{5}(\mathrm{OH})_{4} \cdot 2 \mathrm{H}_{2} \mathrm{O}$ & Silicate & & $\mathrm{x}^{\mathrm{c}}$ & $\mathrm{X}^{\mathrm{d}, \mathrm{e}, \mathrm{g}}$ & & $\mathrm{x}$ & & & & & & & $\mathrm{x}^{\mathrm{m}}$ \\
\hline
\end{tabular}

SEM images show that sulfur deposits (EDX analysis done in the yellow dot in Fig. 4) of Acqua Mintina Cave result intensely corroded, exhibiting linear weathered structures (Fig. 4A) and boreholes (Fig. 4B) on the surface. On the other hand, the sulfur deposits of Santa Cesarea Terme seem to be very porous, showing an overall powdery habit and circular voids. Generally, sulfur deposits are associated with gypsum crystals (EDX analysis in the blue dot) and, as occurring in Acqua Mintina Cave, with celestine minerals (Fig. 5F).

Nevertheless, gypsum and sulfur are not the only speleogenetic by-products found in the SAS caves of Italy. As a matter of fact, we discovered copious powdery
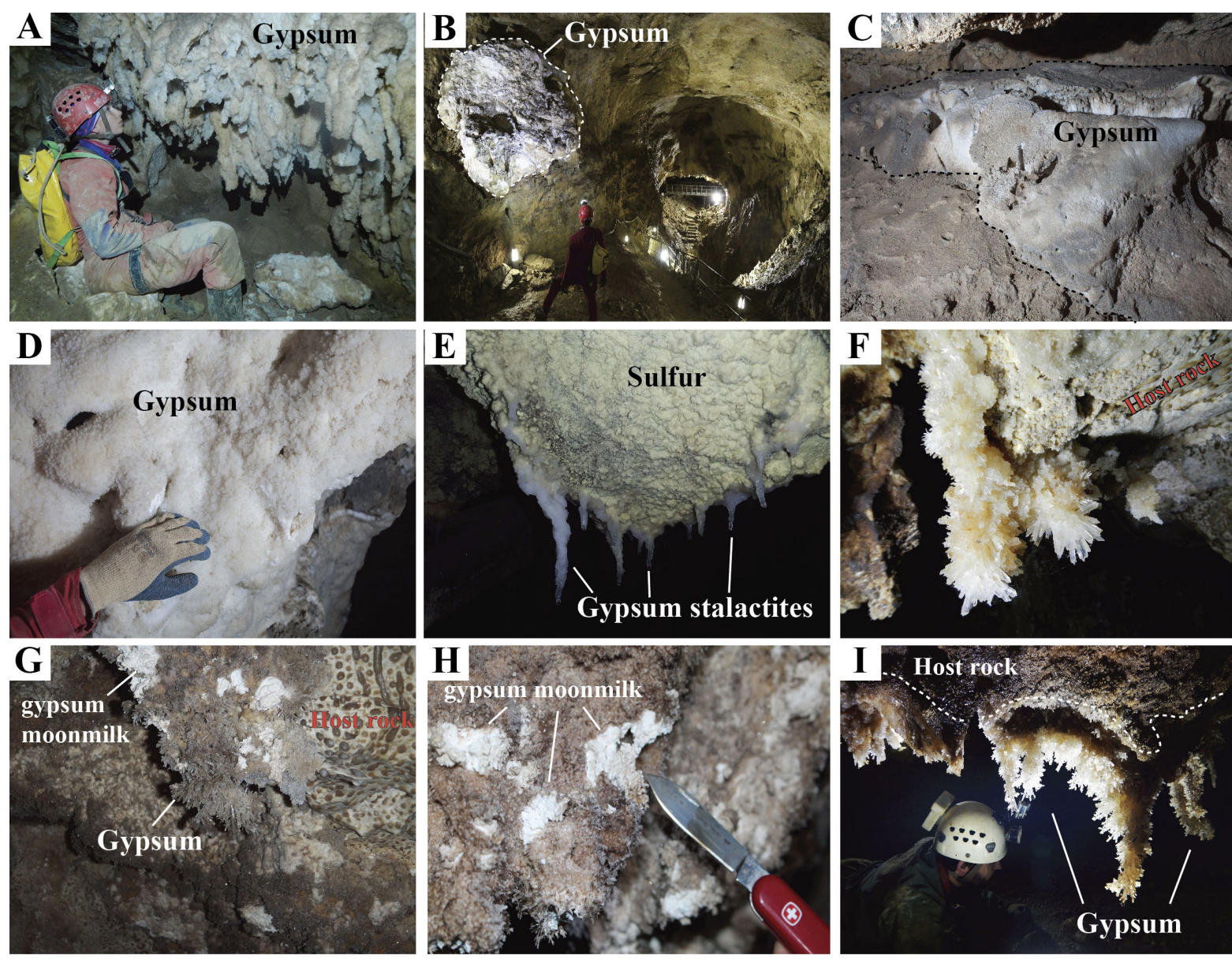

Fig. 2. Gypsum deposits from several SAS caves of Italy; A) Gypsum chandeliers of Faggeto Tondo Cave, Monte Cucco, Umbria (photo J. De Waele); B) Gypsum deposits of Cavallone Cave in Abruzzo (photo G. Antonini); C) Gypsum deposits along a water table level of Gigliola Cave, Cassano allo lonio, Calabria (photo O. Lacarbonara); D) Gypsum deposits in the lower part of Sant'Angelo Cave in Cassano allo lonio, Calabria (photo O. Lacarbonara); E) Sulfur deposits and gypsum stalactites growing on walls and the ceiling of Gattulla Cave, in Santa Cesarea Terme, Apulia (photo M. Parise); F) Gypsum crystals growing on the host rock of Solfatara Cave, in Santa Cesarea Terme, Apulia (photo M. Vattano); G) Gypsum crystals and gypsum moonmilk growing of walls and roof of Fetida Cave, in Santa Cesarea Terme, Apulia (photo M. Parise); H) Gypsum moonmilk on the wall of Fetida Cave, Santa Cesarea Terme, Apulia (photo I.M. D’Angeli); I) Gypsum deposits growing on the ceiling of a small cave close to Acqua Mintina (photo M. Vattano). 
jarosite $\left[\mathrm{KFe}^{3+}{ }_{3}\left(\mathrm{SO}_{4}\right)_{2}(\mathrm{OH})_{6}\right]$ and alunite $\left[\mathrm{KAl}_{3}\left(\mathrm{SO}_{4}\right)_{2}(\mathrm{OH})_{6}\right]$ deposits (Table 2 and Fig. 5). Jarosite has been found in eight cave systems, followed by alunite observed only in five systems (Monte Cucco, Montecchio, Cavallone-Bove, Acqua Mintina, and Corona 'e sa Craba caves). Natroalunite $\left[\mathrm{NaAl}_{3}\left(\mathrm{SO}_{4}\right)_{2}(\mathrm{OH})_{6}\right]$ and tschermigite $\left[\left(\mathrm{NH}_{4}\right) \mathrm{Al}\left(\mathrm{SO}_{4}\right)_{2} \cdot 12 \mathrm{H}_{2} \mathrm{O}\right]$ were found in two caves, while the others such as felsőbányaite $\left[\mathrm{Al}_{4}\left(\mathrm{SO}_{4}\right)(\mathrm{OH})_{10} \cdot 4 \mathrm{H}_{2} \mathrm{O}\right]$, tamarugite $\left[\mathrm{NaAl}\left(\mathrm{SO}_{4}\right)_{2} \cdot 6 \mathrm{H}_{2} \mathrm{O}\right], \quad$ alum- $(\mathrm{K}) \quad\left[\mathrm{KAl}\left(\mathrm{SO}_{4}\right)_{2} \cdot 12 \mathrm{H}_{2} \mathrm{O}\right]$, pickeringite $\left[\mathrm{MgAl}_{2}\left(\mathrm{SO}_{4}\right)_{4} \cdot 22 \mathrm{H}_{2} \mathrm{O}\right], \quad$ walthierite $\left[\mathrm{Ba}_{0.5} \mathrm{Al}_{3}\left(\mathrm{SO}_{4}\right)_{2}(\mathrm{OH})_{6}\right]$, eugsterite $\left[\mathrm{Na}_{4} \mathrm{Ca}\left(\mathrm{SO}_{4}\right)_{3} \cdot 2 \mathrm{H}_{2} \mathrm{O}\right]$, metavoltine $\left[\mathrm{K}_{2} \mathrm{Na}_{6} \mathrm{Fe}^{2+} \mathrm{Fe}^{3+}{ }_{6} \mathrm{O}_{2}\left(\mathrm{SO}_{4}\right)_{12} \cdot 18 \mathrm{H}_{2} \mathrm{O}\right]$, and copiapite $\left[\mathrm{Fe}^{2+} \mathrm{Fe}^{3+}{ }_{4}\left(\mathrm{SO}_{4}\right)_{6}(\mathrm{OH})_{2} \cdot 2 \mathrm{H}_{2} \mathrm{O}\right]$ have been found only in one cave system. Alunite deposits have been abundantly found in Cavallone-Bove system showing a wide suite of different colors going from whitish (Fig. 5A-B) to light brown (Fig. 5D). Jarosite, instead, exhibits colors ranging from yellowish-brown (Fig. 5E), orange (Fig. 5C) to grey, if in association
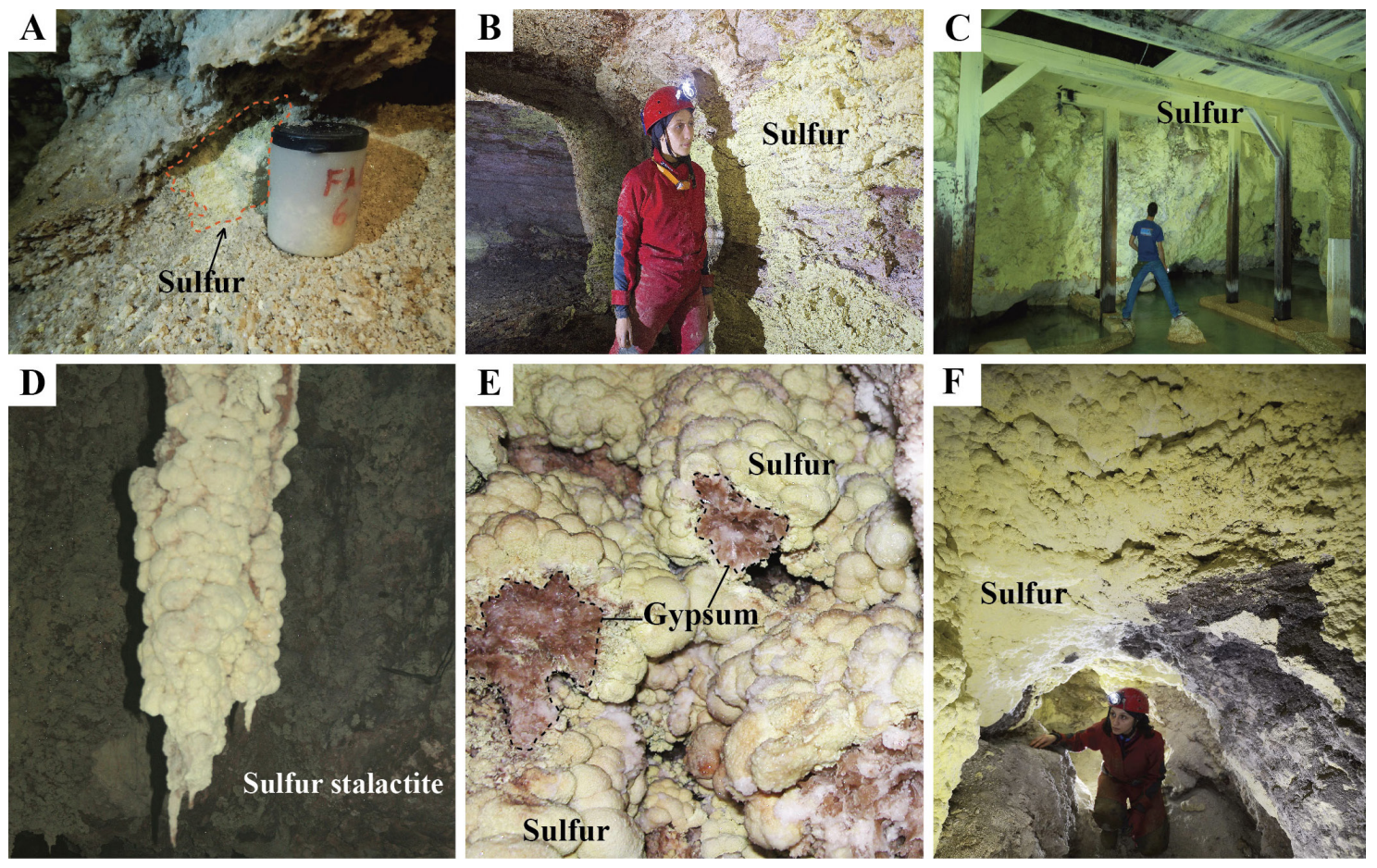

Fig. 3. Sulfur deposits from several SAS caves in Italy; A) Sulfur deposited in little pockets in Faggeto Tondo Cave located in Monte Cucco (photo M. Nagostinis); B) Sulfur deposits on the walls in the lower part of Grotta Nuova, Acquasanta Terme (photo R. Simonetti); C) Sulfur covering walls and ceiling in Gattulla Cave in Santa Cesarea Terme (photo M. Vattano), D) The biggest sulfur stalactite (1.5 m long) of Cala Fetente Cave in Capo Palinuro (photo P. Forti); E) Bothryoidal sulfur deposits covering gypsum speleothems of Cala Fetente Cave in Capo Palinuro (photo P. Forti); F) Sulfur deposited on walls and ceiling of Acqua Mintina Cave (Sicily), and coating a thin layer of organic matter characterized by dark color in the lower part of the picture (photo M. Vattano).
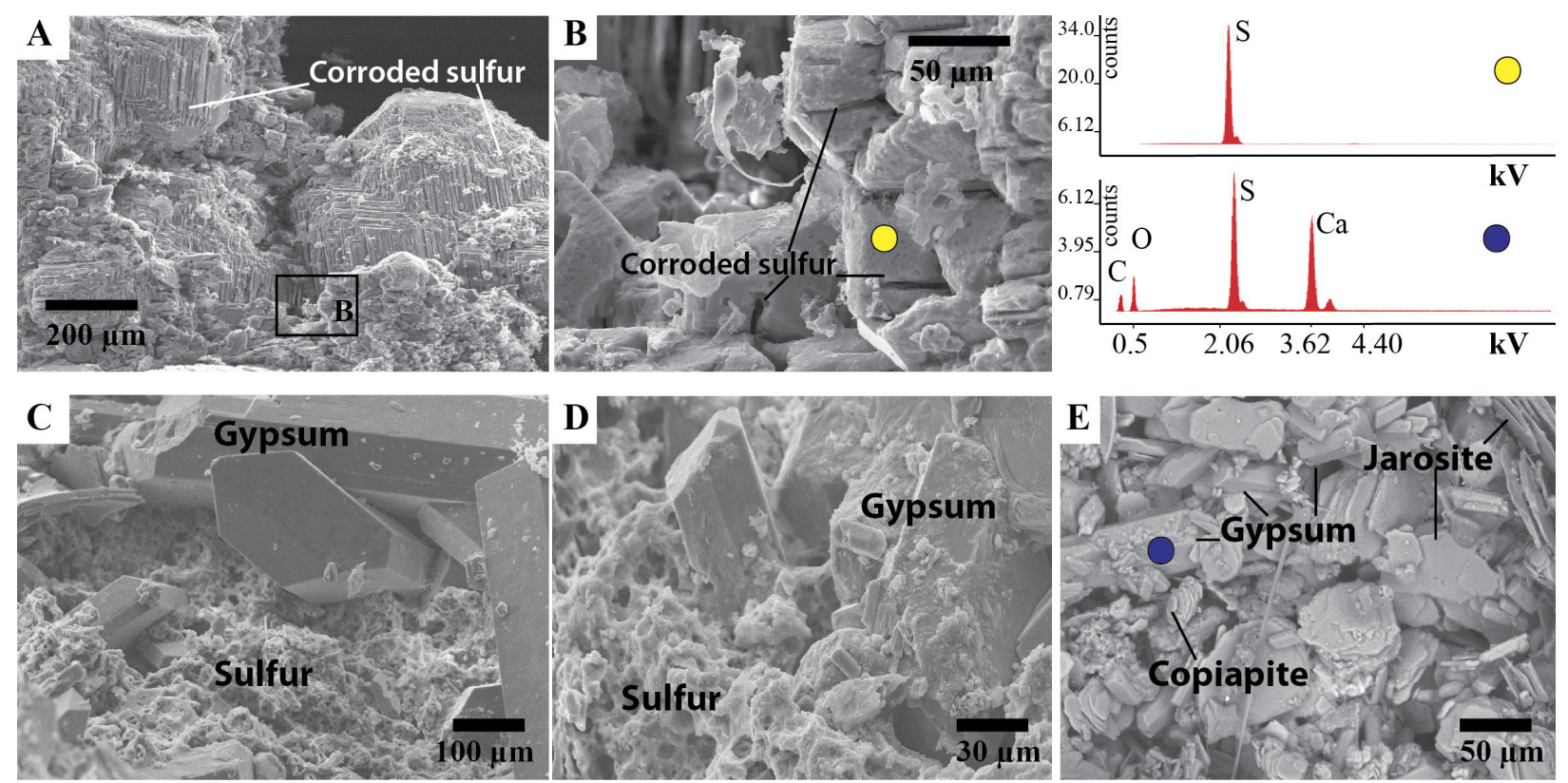

Fig. 4. Sulfur and gypsum deposits observed with Scanning Electron Microscope and EDX analyses; A) Sulfur deposits from Acqua Mintina Cave (Sicily). The crystal faces are deeply corroded. B) A higher magnification allowed us to see both lines of corrosion and interesting etching structures with rounded shapes; C and D) The sulfur deposits of Gattulla Cave in Santa Cesarea Terme (Apulia) have a very porous structure (with circular holes). They are always associated with gypsum crystals. E) Gypsum deposits found in Ninfe Cave (Cerchiara di Calabria) are associated with laminae of jarosite and hexagonal crystals of copiapite. 
with celestine and gypsum (Fig. 5F). SEM images (Fig. 6) show that these deposits are characterized by tiny crystals, sometimes smaller than $2 \mu \mathrm{m}$. EDX analyses allowed us to observe that deposits are not only characterized by pure crystals made of a unique phase, but also by solid solutions of two (Fig. 6A-G) or three (Fig. 6C) mineralogical phases enriched with $\mathrm{P}$ (phosphorus). Alunite and jarosite crystals are, mainly, perfect microcrystalline cubes (Fig. 6B-C-E), but sometimes they have defects such
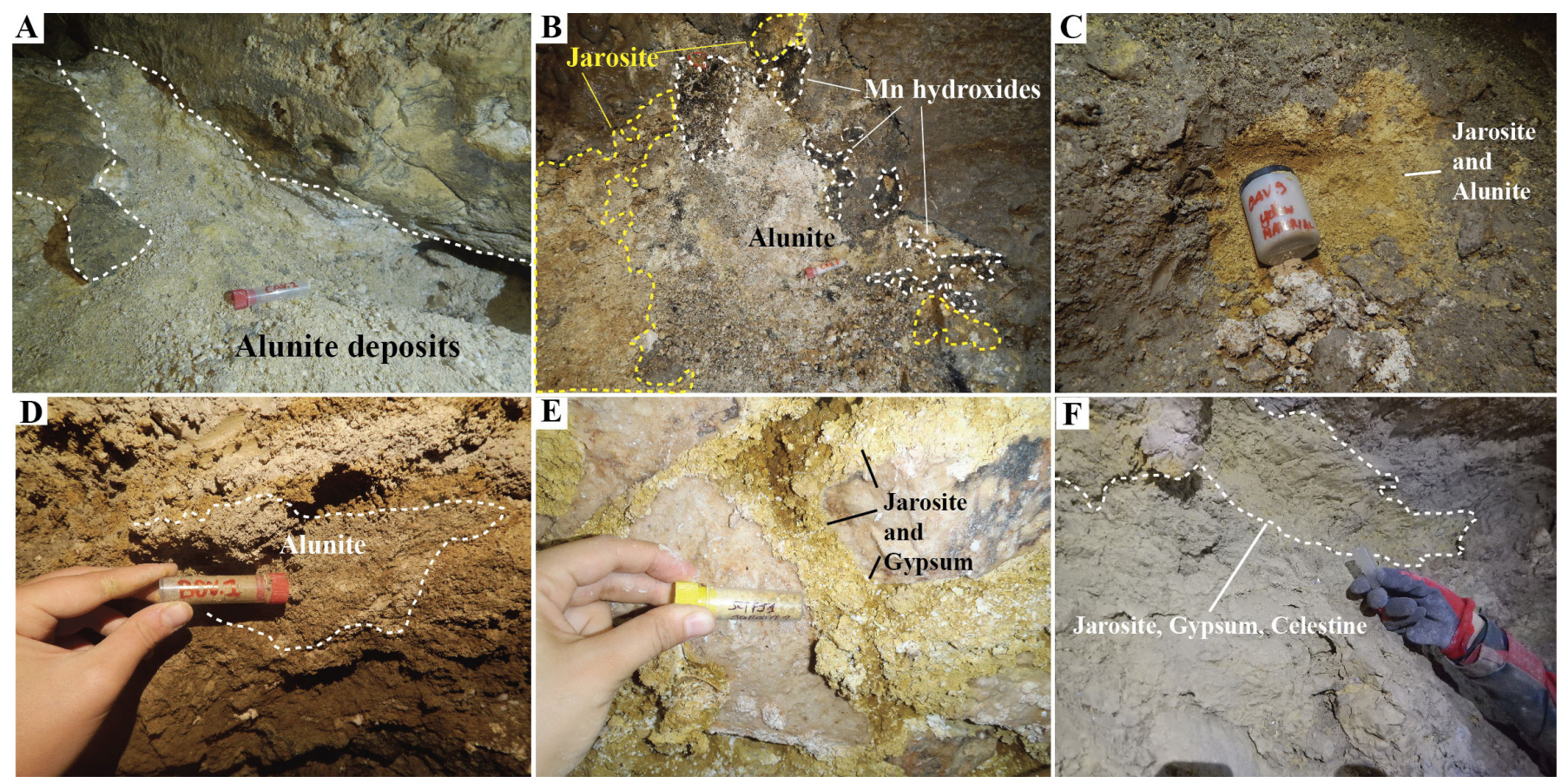

Fig. 5. Appearance of alunite and jarosite deposits; A. Whitish deposits located in Cavallone Cave, Abruzzo. They are dominated by alunite minerals, with a minor amount of jarosite, brucite and quartz minerals (photo M. Nagostinis); B. Deposits with different colors in the innermost part of Cavallone Cave, Abruzzo. The dark materials are made of $\mathrm{Mn}$ hydroxide, silicates and alunite, the brownish sediments of alunite and jarosite, while the greyish ones are characterized by alunite and natroalunite minerals (photo M. Nagostinis); C. Brownish deposits in Cavallone Cave, Abruzzo. They are composed of jarosite, alunite and $10 \%$ of muscovite minerals (photo M. Nagostinis); D. Light brown deposits in Bove Cave, Abruzzo, made of alunite, quartz, muscovite and magnesite minerals (photo M. Nagostinis); E. Jarosite and gypsum deposits found in Fetida Cave, Santa Cesarea Terme, Apulia (photo I.M. D’Angeli); F. Grey-yellowish deposits located in Acqua Mintina Cave, Sicily. They are characterized by jarosite, gypsum, celestine and quartz minerals (photo M. Vattano).

as the case occurring in Fig. $6 \mathrm{H}$, showing square voids on the surface of the jarosite cubes. Alunite can also be characterized by bipyramidal crystals (Fig. 6D). Rounded crystals made of solid solutions of jarosite-alunite have been observed, likely related to subsequent weathering processes (Fig. 6G). In a sample coming from Acqua Mintina we saw tiny jarosite crystals covering quartz (Fig. 6I). Nanostar crystals of $\sim 1 \mu \mathrm{m}$, have been noticed on the surface of perfect cubic alunite minerals: they are, likely, composed of gibbsite (Fig. $6 \mathrm{E}$ ) that formed in a later stage. In the Calabrian cave systems and in Acqua Mintina Cave, we discovered interesting yellowish brown deposits made of quite rare speleogenetic by-products composed of metavoltine, copiapite, pickeringite, hexahydrite $\left[\mathrm{Mg}\left(\mathrm{SO}_{4}\right) \cdot 6 \mathrm{H}_{2} \mathrm{O}\right]$, or tamarugite (Fig. 7). SEM analyses allowed us to elucidate their crystal habits. Metavoltine (Fig. 7A-D) exhibits tabular crystal with hexagonal outlines (EDX analysis carried out in the yellow dot), and developed in association with $\mathrm{Mg}$ sulfates (such as epsomite $\left[\mathrm{Mg}\left(\mathrm{SO}_{4}\right) \cdot 7 \mathrm{H}_{2} \mathrm{O}\right]$ and hexahydrite). Copiapite minerals (Fig. 7E) are tabular with a perfect hexagonal shape and can occur together with gypsum and jarosite deposits (Fig. 4E) or with elongated crystals of pickeringite (Fig. 7E-F) and tabular rhombohedral hexahydrite (Fig. 7F) (EDX analyses are shown, respectively, in the light blue and orange dot).

Rutile $\left[\mathrm{TiO}_{2}\right]$, ilmenite $\left[\mathrm{Fe}^{2+} \mathrm{Ti}^{4+} \mathrm{O}_{3}\right]$, and titanite $\left[\mathrm{CaTi}\left(\mathrm{SiO}_{4}\right) \mathrm{O}\right]$ have been found, especially, in Monte
Cucco and Cavallone-Bove systems (Fig. 8A-B) and EDX analyses are shown in Fig. 9 (yellow-light blueorange dots). SEM images (Fig. 9A-B-C-D) point out their morphology: needle (Fig. 9A) and rhombohedral (Fig. 9D) crystals of rutile, and spherical (Fig. 9C) and rounded (Fig. 9B) crystals of titanite have been observed. We found them in association with solid solutions of alunite-jarosite-natroalunite (Fig. 9C), muscovite $\left[\mathrm{KAl}_{2}\left(\mathrm{Si}_{3} \mathrm{Al}\right) \mathrm{O}_{10}(\mathrm{OH})_{2}\right]$ (Fig. 9A), goyazite $\left[\mathrm{SrAl}_{3}\left(\mathrm{PO}_{4}\right)\left(\mathrm{PO}_{3} \mathrm{OH}\right)(\mathrm{OH})_{6}\right]\left(\right.$ Fig. 9B), or baryte $\left[\mathrm{Ba}\left(\mathrm{SO}_{4}\right)\right]$ (Fig. 9D-E). The fossil branches of several systems such as La Grotta (in Monte Cucco), Frasassi, Sant'Angelo (Cassano allo Ionio), and Corona 'e sa Craba caves host important baryte deposits (Fig. 8C-D), whilst Faggeto Tondo Cave (in Monte Cucco) accommodates significant fluorite $\left[\mathrm{CaF}_{2}\right]$ deposits (Fig. 8E-F-G-H-I). The spectrum of baryte from La Grotta (Fig. 9, blue dot) points out the presence of $\mathrm{Sr}$, likely related to a solid solution between baryte and celestine. Celestine was found also in other SAS systems like Buso della Pisatela-Rana (where it is related to allogenic volcanic sediments brought into the cave), and Acqua Mintina (Fig. 9F), where it is authigenic. Hydroxides such as gibbsite $\left[\mathrm{Al}(\mathrm{OH})_{3}\right]$ and goethite $[\mathrm{FeO}(\mathrm{OH})]$ (Fig. 9I, Fig. 10D-E-F) together with phosphates $\left(\mathrm{PO}^{3-}{ }_{4}\right)$ have been observed and sometimes they occur on the surface of fluorites (Fig. 9G-H-I). Interesting solid solutions of goyazite-alunite-jarosite (Fig. 10A), hydroxylapatite-goyazite (Fig. 10C), and nanocrystals 

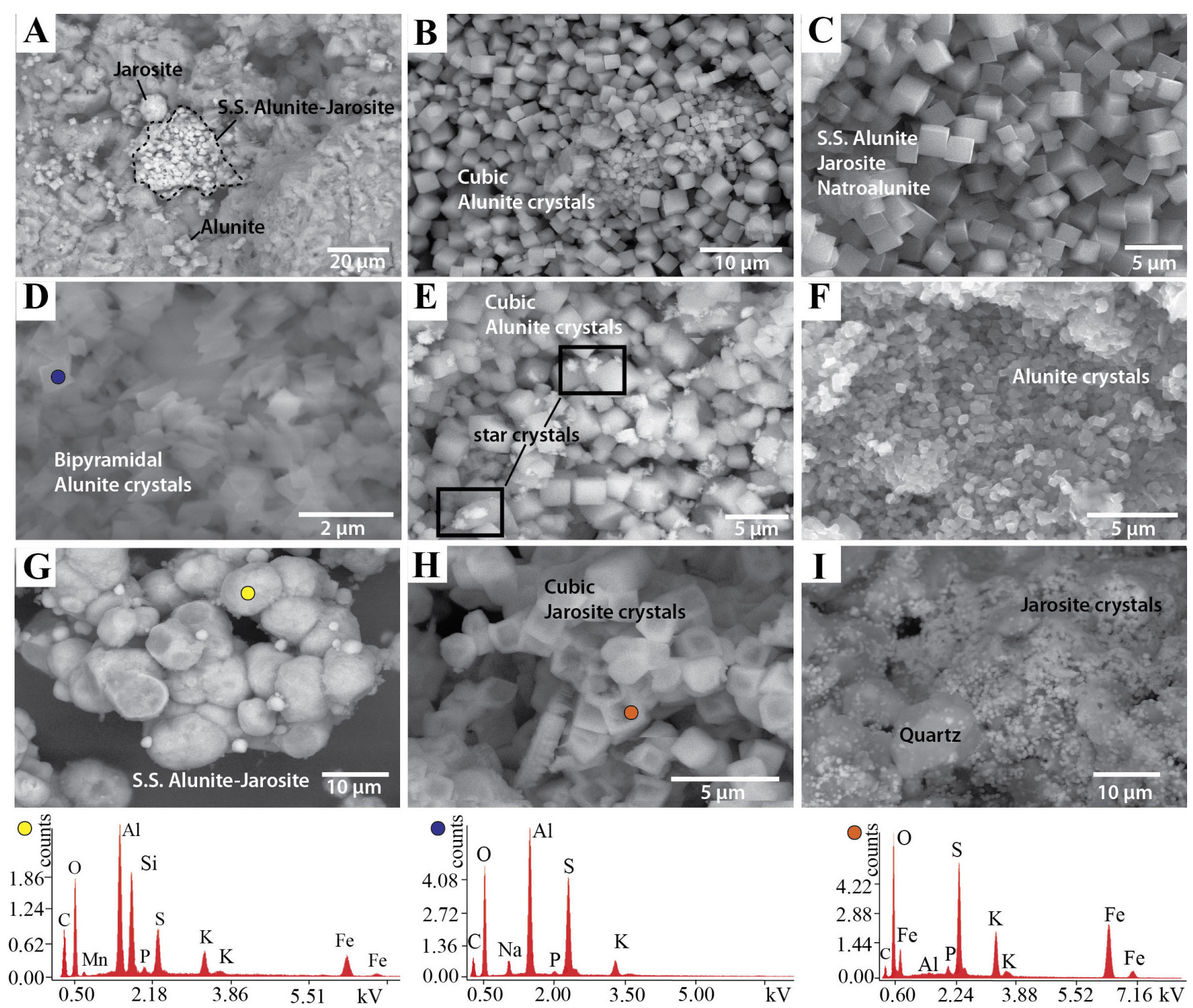

Fig. 6. Alunite and jarosite deposits observed with SEM and some EDX analyses; A) Cubic alunite minerals are found together with pure jarosite crystals and solid solution (S.S.) of alunite-jarosite, Cavallone Cave, Abruzzo; B) Pure alunite crystals with a perfect cubic shape have been observed in Cavallone Cave, Abruzzo; C) Cubic crystals, characterized by a solid solution of alunite-jarosite-natroalunite, have been observed in Bove Cave, Abruzzo; D) Bipyramidal crystals of alunite are present in Cavallone Cave, Abruzzo. The blue dot represents the site of EDX analysis shown in the lower part of the figure; E) Sometimes, the cubic crystals of alunite are covered by star-shaped crystals (dark squares), probably made of gibbsite; F) Small crystals of alunite in Cavallone Cave, Abruzzo; G) Rounded and degraded crystals composed of a solid solution of alunite-jarosite, likely related to secondary weathering processes, found in Cavallone Cave, Abruzzo. The EDX analysis of the yellow dot shows the presence of an important amount of Si, likely related to clay minerals; H) Cubic crystals of jarosite, showing a peculiar defect of crystallization, Bove Cave, Abruzzo. The EDX analysis in the orange dot shows an almost pure jarosite composition; I) Small crystal of jarosite covering quartz minerals, Acqua Mintina Cave, Sicily.

of leucophosphite $\left[\mathrm{KFe}^{3+}{ }_{2}\left(\mathrm{PO}_{4}\right)_{2}(\mathrm{OH}) \cdot 2 \mathrm{H}_{2} \mathrm{O}\right]$ (Fig. $10 \mathrm{C}$ ) are common in the fossil middle branches of La Grotta (Monte Cucco system), whereas hydroxylapatite $\left[\mathrm{Ca}_{5}\left(\mathrm{PO}_{4}\right)_{3}(\mathrm{OH})\right]$, vashegyite $\left[\mathrm{Al}_{11}\left(\mathrm{PO}_{4}\right)_{9}(\mathrm{OH})_{6} \cdot 38 \mathrm{H}_{2} \mathrm{O}\right]$, robertsite $\left[\mathrm{Ca}_{2} \mathrm{Mn}_{3}^{3+} \mathrm{O}_{2}\left(\mathrm{PO}_{4}\right)_{3} \cdot 3 \mathrm{H}_{2} \mathrm{O}\right]$, spheniscidite $\left[\left(\mathrm{NH}_{4}\right) \mathrm{Fe}^{3+}{ }_{2}\left(\mathrm{PO}_{4}\right)_{2}(\mathrm{OH}) \cdot 2 \mathrm{H}_{2} \mathrm{O}\right]$, berlinite(?) [Al $\left.\left(\mathrm{PO}_{4}\right)\right]$, taranakite $\left[\mathrm{K}_{3} \mathrm{Al}_{5}\left(\mathrm{PO}_{3} \mathrm{OH}\right)_{6}\left(\mathrm{PO}_{4}\right)_{2} \cdot 18 \mathrm{H}_{2} \mathrm{O}\right]$ have been detected only in Corona 'e sa Craba Cave, where they are related to bat guano.

\section{DISCUSSION}

As observed in all the Italian sulfuric acid caves, gypsum is the most common secondary mineral, deriving from the immediate reaction between $\mathrm{H}_{2} \mathrm{SO}_{4}$ and the carbonate host rock (see reaction 2), a process well-explained by Egemeier (1981). Abundant gypsum deposits have been found in several famous sulfuric acid caves including Carlsbad Caverns and Lechuguilla in New Mexico (Hill, 1995), Cueva de Villa Luz in Tabasco, Mexico (Hose et al., 2000), Grotte du Chat in France (Audra, 2007; De Waele et al., 2016), Kraushöhle in Austria (Plan et al., 2012), and Movile and Cerna Valley in Romania (Sarbu et al., 1994; Galdenzi, 2001; Onac et al., 2011). Several modes of gypsum precipitation have been described causing, for instance, different structures of cave gypsum deposits, depending on the genetic environment. Buck et al. (1994) classified them in: 1) subaqueous replacement crusts, 2) subaqueous sediments, 3) subaerial replacement crusts, 4) subaerial replacement crust breccias, and 5) evaporitic crusts. In Figure 2A-E-F-I we observed several examples of evaporitic speleothems formed in sub-aerial environments and similar to the ones described by Davis (2000). In Figure 2E gypsum stalactites that lack the central feeding 

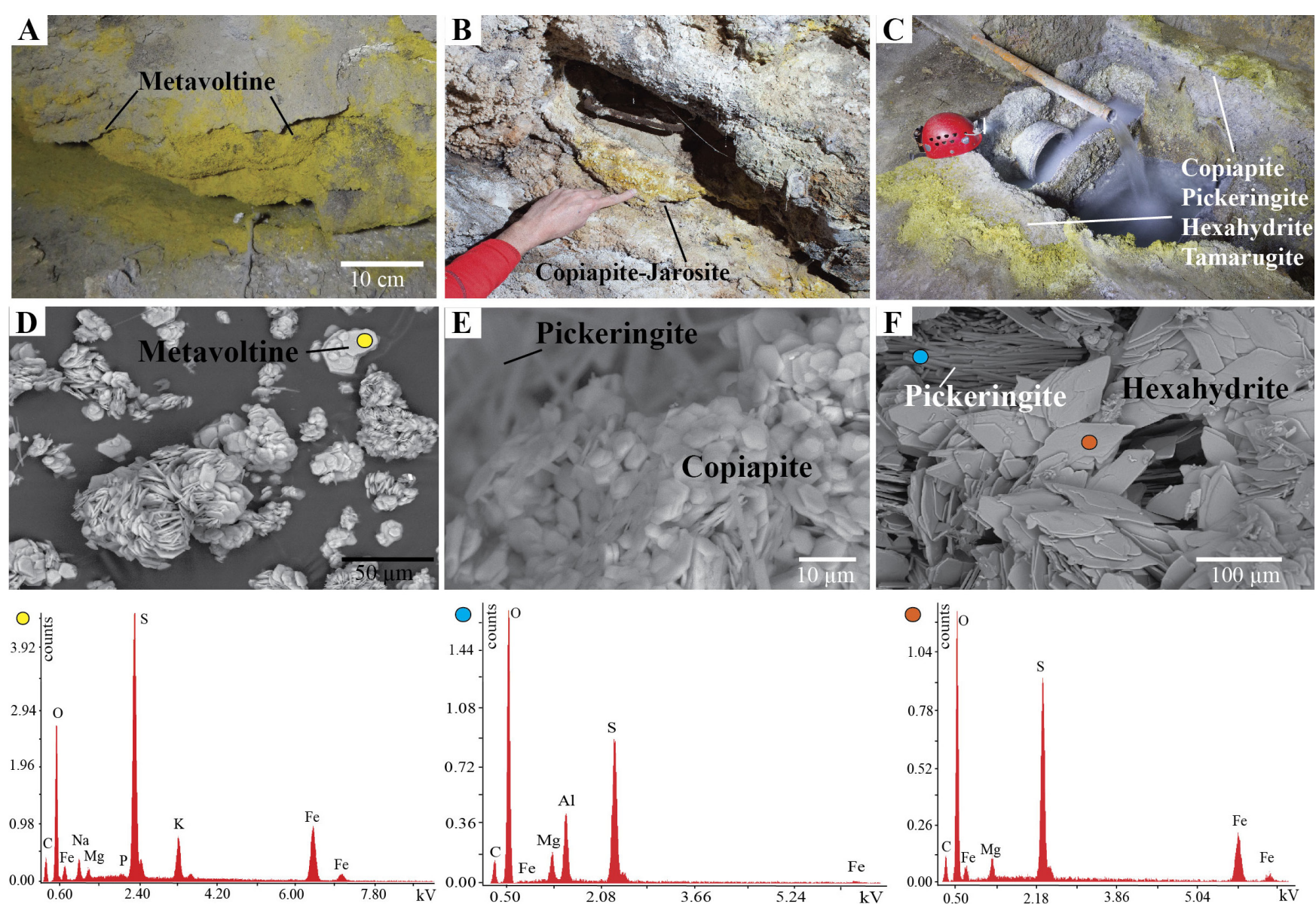

Fig. 7. Yellowish deposits found in some SAS cave of Italy and SEM-EDX analysis; A) Metavoltine-hexahydrite deposits, in Acqua Mintina Cave, Sicily (photo I.M. D'Angeli); B) Copiapite-jarosite deposits found in the spring of Ninfe Cave, Cerchiara di Calabria (photo O. Lacarbonara); C) Copiapite-pickeringite-hexahydrite-tamarugite deposits observed in Terme Sibarite Spring, Cassano allo lonio, Calabria (photo O. Lacarbonara); D) Laminae of metavoltine minerals (the yellow dot represents the site of EDX analysis); E) Hexagonal laminae of copiapite, in the background it is possible to see elongated crystals of pickeringite; F) Pickeringite crystals (site of EDX analysis in the light blue dot), and hexahydrite minerals (EDX analysis in the orange dot).

channels are presented, whilst the speleothems in Figs. 2A-F-I seem to be tiny chandelier stalactites. Their formation is related to airflow convection that leads to several condensation/evaporation cycles (Davis, 2000), inducing the dissolution-corrosion of carbonate rock and, subsequently, its replacement by gypsum materials.

In Figure $2 \mathrm{~B}$ and $\mathrm{C}$ it is possible to observe subaqueous replacement crusts located in inactive SAS caves, such as Cavallone Cave (Fig. 2B) in Abruzzo, and Gigliola Cave (Fig. 2C) in Calabria. They developed parallel to ceilings and walls, but they are currently occurring as collapsed blocks with wellaltered external surface characterized by vertical holes caused by active dripping. In Figure 2D, there are sub-aerial replacement crusts in the fossil SAS cave called Sant'Angelo (Calabria), and nowadays they are subjected to secondary sub-aerial weathering. Figures $2 \mathrm{G}$ and $2 \mathrm{H}$ display sub-aerial gypsum deposits made of creamy moonmilk with a microcrystalline structure and macrocrystalline euhedral needles growing in a still active cave in Apulia (Fetida cave at Santa Cesarea Terme). The genesis of such gypsum moonmilk deposits seems to be related to interesting acidophilic communities of archaea and bacteria, and deserves further studies. They thrive only in the innermost part of the Fetida Cave, where $\mathrm{H}_{2} \mathrm{~S}$ contained in the upwelling waters, reaching the atmosphere, degasses and produces intense condensation- corrosion processes, inducing the dissolution of the carbonate host rock and precipitation of newly formed gypsum minerals.

Gypsum moonmilk deposits have been described in other SAS systems around the world, and especially, in wet environments or where the aggressivity of $\mathrm{H}_{2} \mathrm{SO}_{4}$ is strong enough, such as in Lower Kane Cave in Wyoming (Egemeier, 1981), Guadalupe Mountains in New Mexico (Buck et al., 1994), Cocalière Cave in France, but also in Faggeto Tondo and Fiume-Vento Caves in Central Italy (Cucchi \& Forti, 1988; Forti et al., 1989), and recently in Grotta Bella and Ramo Sulfureo in Frasassi Cave (Mansor et al., 2018).

Sulfur deposits have been found in several locations (Table 2), but they are, really, abundant only in a few Italian cave systems such as: Capo Palinuro (CP), Santa Cesarea Terme (SCT), and Acqua Mintina (AM). They occur in the areas where the sulfuric waters reach the surface producing intense $\mathrm{H}_{2} \mathrm{~S}$ exhalations. As demonstrated by Forti \& Mocchiutti (2004), the sulfur cannot deposit directly on carbonate rock (because of its buffering capacity). In Cala Fetente (Fig. 3D-E), it has been observed that sulfur starts to grow on gypsum minerals only when the concentration of $\mathrm{H}_{2} \mathrm{SO}_{4}$ rapidly increases, whilst $\mathrm{Ca}^{2+}$ (related to carbonate dissolution) decreases (Forti \& Mocchiutti, 2004). In Santa Cesarea Terme (Fig. 3C), as in Cala Fetente, sulfur developed on top of gypsum, completely covering cave walls and man-made wooden 

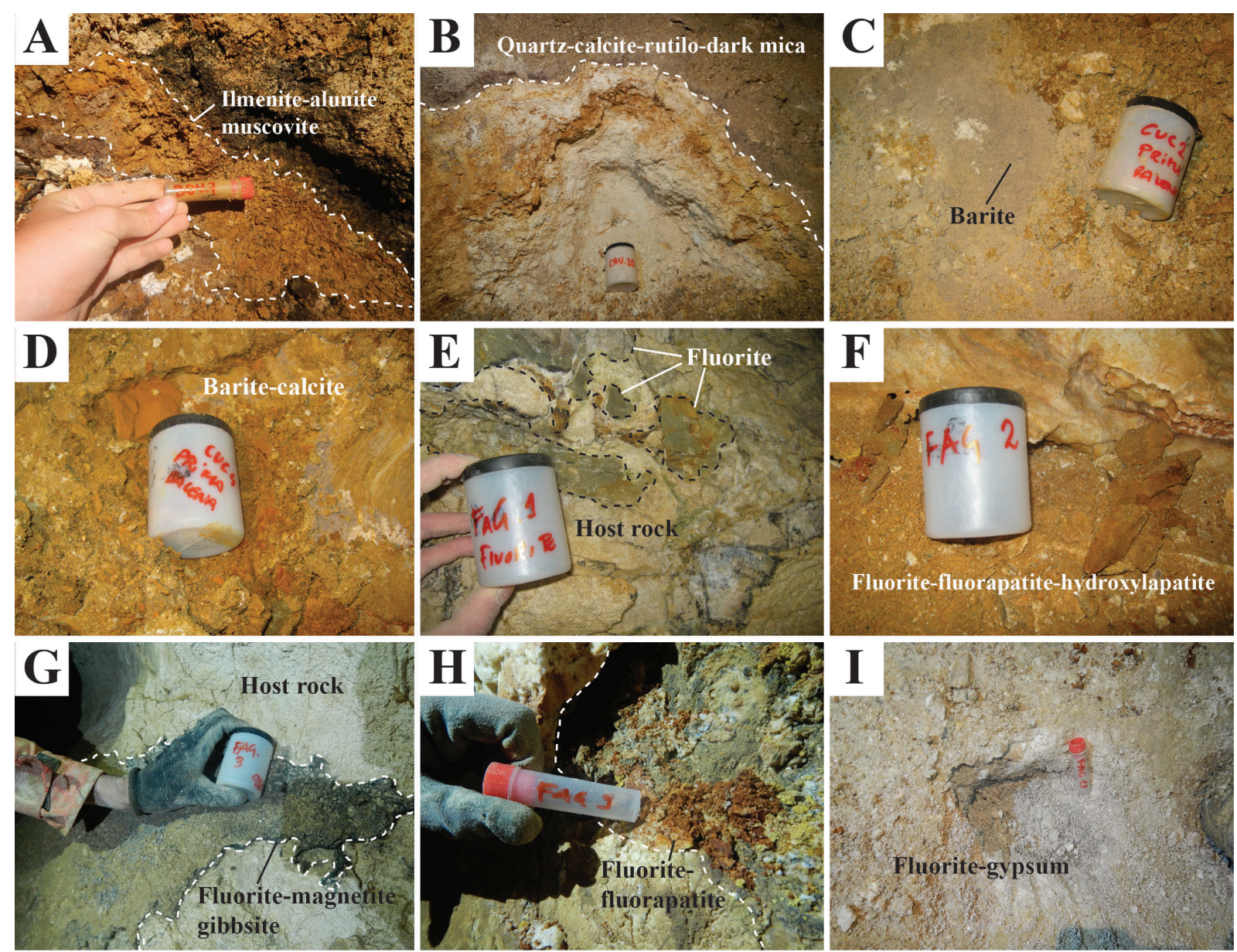

Fig. 8. Appearance of deposits containing ilmenite, rutile, baryte, fluorite, fluorapatite minerals. A) Reddish-brown deposit characterized by ilmenite, alunite and muscovite, located in Cavallone-Bove system (photo M. Nagostinis); B) Grey-browinsh deposit containing rutile minerals, in Cavallone-Bove system (photo M. Nagostinis); C) Greyish deposits of baryte, in the deepest part of La Grotta, Monte Cucco (photo J. De Waele); D) Orange-yellowish deposits characterized by baryte and calcite, in the deepest part of La Grotta, Monte Cucco (photo J. De Waele); E) Green-greyish fluorite deposits in contact with the carbonate host rock, in the upper part of Faggeto Tondo, Monte Cucco system (photo J. De Waele); F) Orange-brownish deposits made of fluorite-fluorapatite and hydroxylapatite, in Faggeto Tondo, Umbria (photo J. De Waele); G) Weathered fluorite, gibbsite and magnetite deposits in contact with the host rock (limestones), in Faggeto Tondo Cave, Umbria (photo M. Nagostinis); H) Brownish deposits made of fluorite and fluorapatite, in the middle part of Faggeto Tondo, Umbria (photo $\mathrm{M}$ Nagostinis); I) Whitish fluorite and gypsum, in the middle-lower part of Faggeto Tondo, Umbria (photo M. Nagostinis).

structures. Otherwise, in Acqua Mintina Cave (Sicily), sulfur grows (Fig. 3F) on a dark material characterized by organic matter, at the external weathered rocksurface characterized by gypsum and celestine, as a result of carbonate replacement. Generally, the observed sulfur deposits are more than $1 \mathrm{~cm}$ thick and present a fine lamination as in the case of Santa Cesarea Terme (D'Angeli et al., 2017a). Well-developed sulfur folia have been described by Lugli et al. (2016) in Acqua Mintina Cave.

As shown in Figure 4, sulfur minerals exhibit linear corrosive structures (Fig. 4A-B), microscopic boreholes (Fig. 4C), porous and powdery habits (Fig. 4C-D). Sometimes it is possible to see filaments, likely related to biological activity (D'Angeli et al., 2017a). As a matter of fact, in Santa Cesarea Terme, a still active sulfuric acid system, we found and collected interesting biological substances including creamy white moonmilk deposits, vermiculations, and white substances floating on the water surface close to the spots where fluids are upwelling (D'Angeli et al., 2017b). The role of sulfur-oxidizing and sulfurreducing microorganisms has been demonstrated to be important in the sulfur cycle (Hill, 1992, 1995; Canfield, 2001, Mansor et al., 2018). It is well known that "purple sulfur bacteria" such as Chromatiales (Chromatiaceae and Ectothiorhodospiraceae) can use sulfide as sole electron donor and precipitate elemental sulfur inside or outside the cells, during oxidation (Imhoff, 2006). Intracellular storage of elemental sulfur allows their endogenous respiration under dark and oxidative conditions (cave environment), whilst it can be used as an electron acceptor during endogenous fermentation of carbohydrates (Imhoff, 2006 and references therein) in dark anoxic (deepseated) environments.

Significant baryte deposits have been described in Monte Cucco (Forti et al., 1989), Frasassi (Perna, 1973), Cassano allo Ionio (Catalano et al., 2014), and Corona 'e sa Craba (Sauro et al., 2014).

In Monte Cucco cave system baryte occurs in association with fluorite. This paragenesis might invoke Mississippi Valley-type ore deposition, formed during large-scale orogenic events (Hanor, 2000). As demonstrated by Barbieri et al. (1982) the interaction between Ba-bearing $(>7,000 \mathrm{ppm})$ deep fluids in contact with phyllites of the basement (Ba exists in solid solutions with $\mathrm{K}$ in minerals like $\mathrm{K}$-feldspar and $\mathrm{K}$-micas) and deep-seated Triassic evaporites allowed the deposition of baryte minerals in Tuscany. 

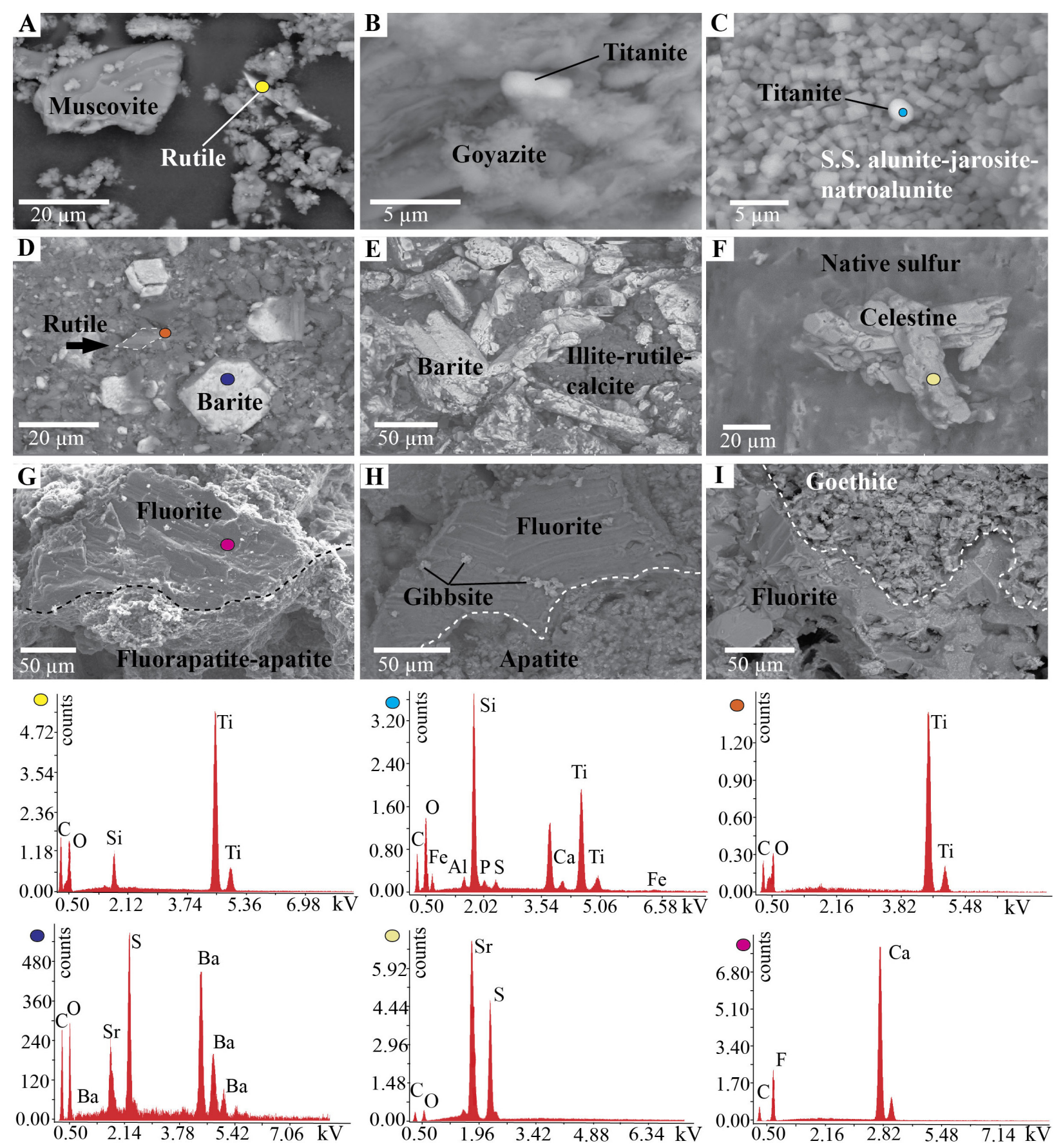

Fig. 9. SEM and EDX analyses of the deposits reported in Fig. 8 A. The SEM image shows an elongated rutile crystal found in Cavallone-Bove system, Abruzzo (EDX analysis in the yellow dot); B) Rounded crystal of titanite found in the middle branches of La Grotta, Monte Cucco, Umbria; C) Sphere of titanite, while the background is dominated by a solid solution of alunite-jarosite, La Grotta, Monte Cucco, Umbria (EDX analysis in the light blue dot); D) The image shows an assemblage of rhombohedral rutile and baryte crystals found in the lower branches of La Grotta, Monte Cucco, Umbria (EDX analysis of rutile and baryte in the orange and blue dots); E) Baryte deposits associated with illite, found in the lower branches of La Grotta, Monte Cucco, Umbria; F) Celestine found in Acqua Mintina Cave, Sicily (EDX analysis in the beige dot); G) Cubic fluorite surrounded by fluorapatite and hydroxylapatite microcrystalline deposits due to weathering, in the upper part of Faggeto Tondo Cave, Monte Cucco, Umbria (EDX analysis in the magenta dot); $\mathrm{H}$ ) Fluorite covered by hydroxylapatite and gibbsite, due to weathering processes, Faggeto Tondo Cave, Umbria; I) Fluorite in association with goethite, found in the lower branches of Faggeto Tondo Cave, Umbria.

Barium can precipitate only in limited conditions, such as $>10 \mathrm{ppm}$ of $\mathrm{Ba}$ content, high salinity ranges $(10,000-30,000 \mathrm{ppm}),<200 \mathrm{ppm}$ of sulfates, otherwise the Ca-sulfate precipitation is favored (Hanor, 2000 and references therein). In $\mathrm{SO}_{4}$-rich environments, $\mathrm{Ba}$ can be mobilized, as barium chloride, only in highly reducing conditions, when sulfates are completely reduced (Hanor, 2000; Sauro et al., 2014). Instead, celestine $\left(\mathrm{SrSO}_{4}\right)$ might be deposited when fluids with an extremely high $\mathrm{Sr} / \mathrm{Ba}$ content (in condition of high salinity, high $\mathrm{SO}_{4}{ }^{2-}$, and low $\mathrm{Ba}^{2+}$ concentration) reacted with evaporite-carbonate rocks. The most famous occurrence of celestine deposits in cave, as described by Wright (1898) and reported in Hill \& Forti (1997), occurs in Crystal Cave (Put-in-Bay, Ohio), but other celestine deposits associated with gypsum have been described in Cumberland Caverns (Tennessee), Flint-Mammoth Caves (Kentucky) and Carlsbad Caverns (New Mexico) (Hill, 1981; Hill, 1987).

Celestine, in the Italian SAS caves, has been observed, especially, in the Buso della Pisatela-Rana (Tisato et al., 2012) as inclusion in volcanic allogenic pebbles, in Acqua Mintina strictly associated with carbonate host rock and gypsum deposits, and in Monte Cucco 

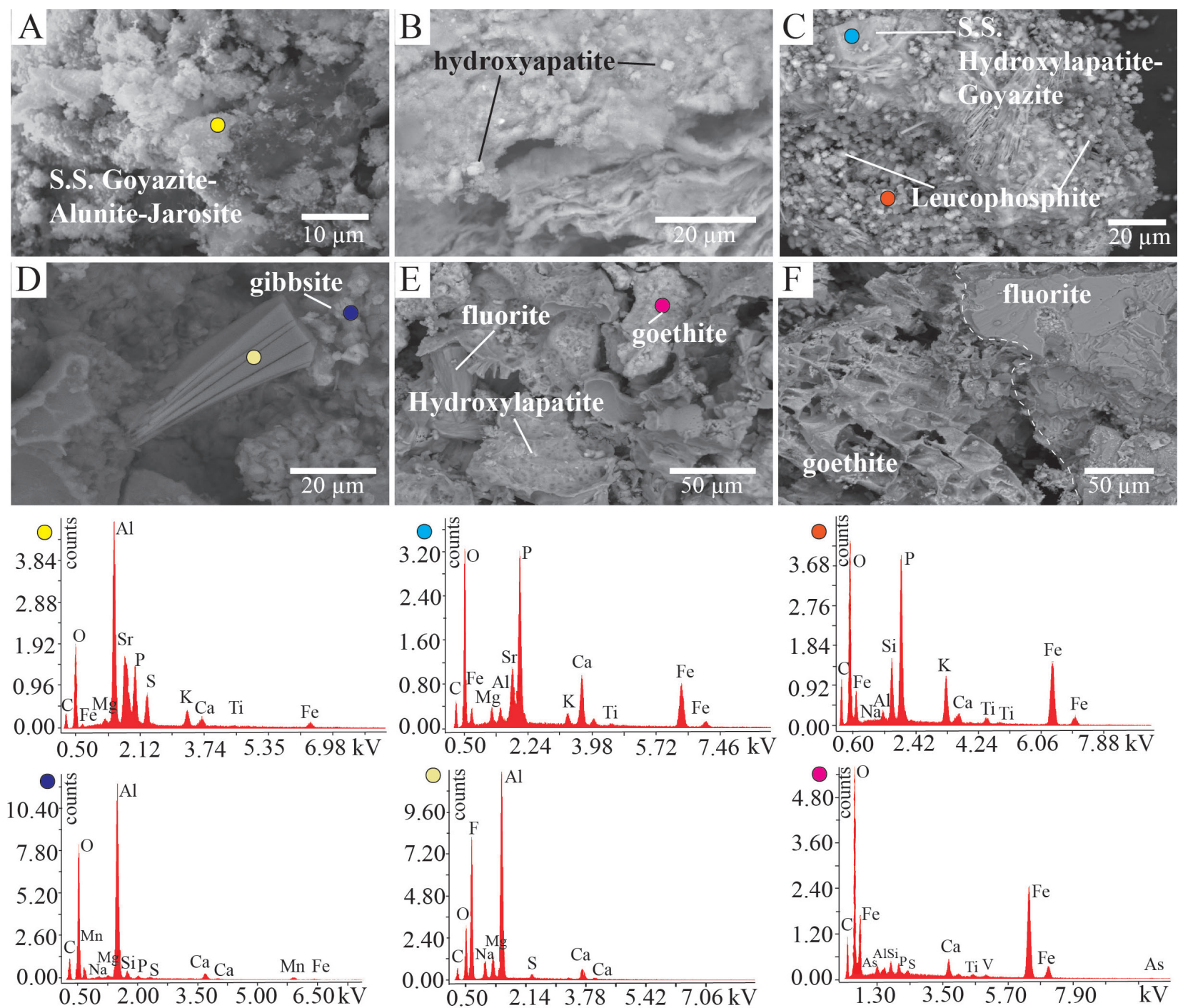

Fig. 10. SEM and EDX analyses of phosphates, aluminum-phosphates and hydroxides of Al and Fe. A) It is possible to see the appearance of a solid solution of goyazite-alunite-jarosite, found in the middle galleries of La Grotta, Umbria (EDX analysis is reported in the yellow dot); B) Cubic hydroxylapatite crystals found in association with goyazite and alunite-jarosite, La Grotta, Monte Cucco; C) The picture shows an assemblage of hydroxylapatite-goyazite solid solution (light blue dot) and leucophosphite (orange dot), La Grotta, Umbria; D) Gibbsite associated with fluorite (EDX in the dark blue dot). A laminated mineral made of Al, F and O, is visible (EDX in the beige dot); E) Goethite (EDX in magenta dot) is also present in association with hydroxylapatite and fluorite crystals in La Grotta, Monte Cucco, Umbria. From the EDX of goethite it is possible to observe elements such as As, V, Ti; F) The picture shows the association of fluorite and goethite in more detail.

system (Forti et al., 1989) in assemblage with baryte deposits. In Acqua Mintina, celestine likely deposited when $\mathrm{SO}_{4}$ and Sr-rich fluids, related to sulfuric acid processes, interacted with the host rock, inducing the precipitation of $\mathrm{SrSO}_{4}$ and gypsum as replacement of carbonate. SEM observations on some samples of baryte from La Grotta (Monte Cucco) show minerals with perfect crystalline habits (Fig. 9D), indicating they formed in situ. In fact, barite is highly resistant in oxidizing environments, and the interaction with sulfuric acid waters, enhancing dissolution-corrosion of carbonate rocks, aids in stabilizing its crystallization. Nevertheless, as visible from EDX analysis (in the blue dot of Fig. 9), baryte is enriched in Sr, indicating a solid solution between baryte-celestine. Complete solid solutions between $\mathrm{Ba}\left(\mathrm{SO}_{4}\right)$ and $\mathrm{Sr}\left(\mathrm{SO}_{4}\right)$ occur due to the similarity of their ionic radii ( 1.16 and $1.36 \AA$ for $\mathrm{Sr}$ and $\mathrm{Ba}$, respectively); moreover, the incorporation of $\mathrm{Sr}^{2+}$ into baryte is facilitated at room temperature (Hanor, 2000). This occurrence would suggest the replacement of early baryte with Sr-rich baryte that might have happened when the temperature of the mother-solution was close to room temperature, and the concentration of sulfate was too low to precipitate $\mathrm{Ca}\left(\mathrm{SO}_{4}\right) \cdot 2 \mathrm{H}_{2} \mathrm{O}$. The rising acidic waters, involved in the sulfuric acid speleogenesis are normally aggressive toward carbonates, and the dissolution of the host rock, due to sulfuric acid, might have increased the concentration of $\mathrm{Sr}^{2+}$ (stable in saline and high $\mathrm{SO}_{4}{ }^{2-}$ habitat) and the possibility of a secondary substitution of $\mathrm{Ba}^{2+}$ (in baryte) with $\mathrm{Sr}^{2+}$. In addition, baryte (Fig. $8 \mathrm{C}-\mathrm{D}$ ) and fluorite (Fig. 8E-F-G-H-I) deposits of Monte Cucco systems exhibit an altered appearance with rusty colors. Fluorite (Fig. 9G) sometimes occurs as perfect cubes with weathered surfaces covered by fluorapatite $\left[\mathrm{Ca}_{5}\left(\mathrm{PO}_{4}\right)_{3} \mathrm{~F}\right]$-hydroxylapatite $\left[\mathrm{Ca}_{5}\left(\mathrm{PO}_{4}\right)_{3}(\mathrm{OH})\right]$ (Fig. 9G), gibbsite (Fig. 9H) and/or goethite (Fig. 9I). The spectrum of goethite, grown in contact with fluorite (Fig. 10 dot in magenta color), is enriched with peculiar trace elements such as As and V.

Baryte and fluorite deposits have been observed in Luceram Cave (French Alps), and its association with vanadium and uranium materials has been found in Khaidarkan and Ferghana caves (Kirghizistan) and in 
some thermal springs in Hungary (Hill \& Forti, 1997). They are thought to be deposited from hydrothermal fluids with temperature $>150-180^{\circ} \mathrm{C}$.

As suggested by Williams-Jones et al. (2000) fluorite can form when hydrothermal fluids $\left(400^{\circ} \mathrm{C}\right.$ characterized by sulfate-rich $\mathrm{NaCl}-\mathrm{KCl}$ brines) meet $\mathrm{CO}_{2}$-bearing and sulfate-poor $\mathrm{NaCl}$ brines of external origin. The mixing between REE-fluoridebearing fluids and Ca-carbonate-bearing fluids (or the interaction with carbonate rocks) is an important control of REE-fluorocarbon mineral deposition (Williams-Jones et al., 2000).

Monte Cucco cave system also hosts magnetite $\left[\mathrm{Fe}^{2+} \mathrm{Fe}^{3+}{ }_{2} \mathrm{O}_{4}\right]$. The stability of baryte-magnetite occurs in limited conditions characterized by $\mathrm{pH}$ ranging between 10-12 and $\log \mathrm{f}_{\mathrm{O} 2}-57$, suggesting that magnetite, probably, precipitated in deep-seated conditions and reached the cave environment through the ascending flows.

Interesting is the association of baryte, pyrite $\left[\mathrm{FeS}_{2}\right]$, and hematite $\left[\mathrm{Fe}_{2} \mathrm{O}_{3}\right]$ observed in Sant'Angelo Cave (Cassano allo Ionio) typical of $\mathrm{pH}$ ranging between 0 and 4 and highly oxidizing conditions (log $\mathrm{f}_{\mathrm{O} 2}$ between -52 and -47) (Hanor, 2000 and references therein), whereas in Corona 'e sa Craba the study of fluid inclusions found in baryte suggests their deposition at a temperature lower than $50^{\circ} \mathrm{C}$, only when the rising reducing fluid became more oxidative (Sauro et al., 2014).

Of significant interest are the assemblages of titanite-rutile crystals in Monte Cucco and titaniterutile-ilmenite in Cavallone-Bove caves, shown in Table 2. The solubility of titanium is very low, and if transported by water flows, it occurs as a solid phase. Nevertheless, Ti can be found in the ionic form due to highly exothermic reactions linked to acid digestion $\left(\mathrm{HNO}_{3}\right.$ and/or $\left.\mathrm{H}_{2} \mathrm{SO}_{4}\right)$ (Westerhoff et al., 2011). The important role of sulfur in some replacement reactions has also been described by Tracy \& Robinson (1988) and Henry \& Guidotti (2002). The breakdown of muscovite flakes releases $\mathrm{Fe}, \mathrm{Si}, \mathrm{Al}$, and $\mathrm{K}$ necessary to the growth of dark micas $\left[\mathrm{K}\left(\mathrm{Mg}, \mathrm{Fe}^{2+}\right)_{3} \mathrm{AlSi}{ }_{3}(\mathrm{OH}, \mathrm{F})_{2}\right]$ within ilmenite deposits (Carswell \& O’Brien, 1993; Angiboust \& Harlov, 2017). Titanium ions can precipitate as: 1) spheres of $\left.\mathrm{TiO}_{2}, 2\right)$ aluminosilicates with a flaky appearance (with absorbed surface iron and/or in association with kaolinite deposits), and 3) mixed environmental silicates without aluminum. In Figure 9, several crystalline morphologies for rutile (Fig. 9A-D) and titanite (Fig. 9B-C) have been pointed out, suggesting titanium was in solution and not only transported as particles by the slowly rising fluid. Rutile shows needle crystals (Fig. 9A) and perfect rhombohedral structure (Fig. 9D), whereas titanite has rounded (Fig. 9B) to spherical appearances.

Rising waters, enriched in $\mathrm{H}_{2} \mathrm{~S}$, can also produce an extensive suite of insoluble $\mathrm{pH} /$ Eh-dependent hydroxysulfates and oxyhydroxides (Carbone et al., 2013) and APS materials of significant value for extractive and environmental geology (Dill, 2001). Fe-rich waters precipitate yellow-to red-to brown materials, while Al-rich fluids form milky-white precipitates (Bigham \& Nordstrom, 2000; Carbone et al., 2013). Acidity (pH) is one of the most significant limiting factors in sulfuric-acid solutions, being Fe and Al pH-dependent (Tombácz et al., 2000). Generally, $\mathrm{Al}^{3+}$ is stable in quite acid conditions $(\mathrm{pH}<5)$, and the conservative solute transport values for $\mathrm{Fe}^{3+}$ are limited in comparison to the species $\mathrm{Fe}^{2+}$. In fact, $\mathrm{Fe}^{3+}$ is stable at very low $\mathrm{pH}(<1)$ and $\mathrm{Eh}$ ranging between 0.8 and 1.8 , while $\mathrm{Fe}^{2+}$, depending on the potential values $(-0.4$ to 0.8$)$, starts to precipitate from very acidic $(\mathrm{pH}$ $<1$ ) to neutral ( $\mathrm{pH}=7$ ) conditions. In non-sulfuricacid conditions $\mathrm{Fe}$ and $\mathrm{Al}$ oxides, hydroxides, and oxyhydroxides typically occur at $\mathrm{pH}$ ranging between 5 and 9 (Stumm, 1992). The presence of dissolved $\mathrm{SO}_{4}{ }^{2-}$ in water changes the conservative solute transport threshold, inducing a drop of $\mathrm{pH}$ value $(<4.5)$ and decreasing the areas of stability for $\mathrm{Al}^{3+}, \mathrm{Fe}^{3+}$ and $\mathrm{Fe}^{2+}$. In this circumstance, $\mathrm{Al}^{3+}$ can stay in solution at $\mathrm{pH}$ $<4.5$, whilst the solubility of Fe species is controlled by jarosite and goethite precipitation (Bigham \& Nordstrom, 2000).

Commonly, Al-rich sulfates precipitate separately from Fe-rich ones. Even if present in the same deposits, alunite and jarosite rarely belong to the same event (Rye et al., 1993; Stoffregen, 1993). Minerals belonging to the jarosite group normally form at $\mathrm{pH}$ $<2.5$, alunite precipitates at $\mathrm{pH}$ values of $3-4$, and ferrihydrite $\left[\left(\mathrm{Fe}^{3+}{ }_{10} \mathrm{O}_{14}(\mathrm{OH})_{2}\right]\right.$ (Kulp et al., 2009) with microcrystalline gibbsite at $\mathrm{pH}$ ranging from 6-8. (Bigham \& Nordstrom, 2000).

Alunite, natroalunite, and jarosite deposits have been described in several famous SAS systems around the world (Palmer \& Palmer, 1992; Polyak \& Güven, 2000; Polyak \& Provencio, 2001). Table 2 shows that the most abundant hydroxysulfate, in Italian SAS systems, is jarosite. Jarosite formation, generally, requires more extreme acidity and oxidizing conditions with respect to alunite. On the contrary of alunite (easily attributed to hypogene processes), jarosite is commonly considered a product of supergene weathering (Dill, 2001), and can replace alunite when the fluids become more acidic and oxidizing (Stoffregen et al., 2000). The occurrence of jarosite deposits has also been documented during dry summer seasons in sea caves along the coast in the central part of California (Rogers, 1988; Hill \& Forti, 1997). However, jarosite can also form in highly oxidizing fluids at temperature ranging between 150$200^{\circ} \mathrm{C}$, rich in sulfuric-acid.

As reported by Dutrizac \& Jambor (2000) and Stoffregen et al. (2000) jarosite, in surficial conditions, typically alters to goethite, whereas in low-temperature metamorphic environments the destruction of jarosite produces goethite and hematite. Changes in $\mathrm{pH}$ (due to the addition of a buffering agent such as carbonate rocks) can induce the precipitation of dissolved $\mathrm{Fe}$ (in low concentration), and the deposition of goethite (Dutrizac \& Jambor, 2000 and references therein). Jarosite abundance increases with decreasing $\mathrm{pH}$, whereas goethite is stable at $\mathrm{pH}$ 3.3-3.6 (Bigham \& Nordstrom, 2000). The source of iron can be related to the sedimentary deposition of iron-rich formations along margins of cratons or continental platforms over extended periods of time (Gross, 1983). 
Aluminum in natural environments is related to the weathering of various aluminosilicates including $\mathrm{K}$-feldspar $\left[\mathrm{KAlSi}_{3} \mathrm{O}_{8}\right]$, muscovite, and kaolinite $\left[\mathrm{Al}_{2} \mathrm{Si}_{2} \mathrm{O}_{5}(\mathrm{OH})_{4}\right]$ (Bigham \& Nordstrom, 2000). Alunite can also be due to the interaction between $\mathrm{H}_{2} \mathrm{SO}_{4}$ and illite-series at pH 3-4 (Goldbery, 1980). The studied alunite deposits (Fig. 6) present fine-grained structures, occurring like pseudo-cubic to bipyramidal grains $(0.7-2.5 \mu \mathrm{m})$, deposited as bedded sediments. Jarosite has been observed both with a pseudo-cubic (Fig. 6H) or laminar structure (Fig. 4E). The pseudocubic crystals (Fig. 6H) found in Cavallone-Bove system present evident defects, probably linked to a complete substitution of previous alunite deposits. As suggested by Stoffregen et al. (2000), fine-grained alunite usually forms at quite low temperature. Bigham \& Nordstrom (2000) observed precipitation of alunite crystals after the mixing of acid mine waters with carbonate-rich warm $\left(20^{\circ} \mathrm{C}\right)$ fluids with elevated concentration of chloride (700-800 ppm). Microcrystalline alunite also forms in evaporative conditions together with silica speleothems in Australian caves at room temperature (Wray, 2011). Sulfate in this case derives from pyrite oxidation, and reaches high-enough concentrations because of intense evaporation. Copious solid solutions (Fig. 6 and 10A) have been found in the studied samples, especially those from Cavallone-Bove and Monte Cucco systems. The most common solid solution series are alunite-natroalunite, jarosite-natrojarosite, alunite-jarosite, but interesting are the coupled substitutions of sulfate $\left(\mathrm{SO}_{4}{ }^{2-}\right)$ with phosphate $\left(\mathrm{PO}_{4}{ }^{3}\right)$ or arsenate $\left(\mathrm{AsO}_{4}{ }^{3-}\right)$. Hydroxylapatite replacements can occur in zones of "advanced argillitic" alteration (Stoffregen et al., 2000), defined by the assemblage of kaolinite, alunite, smectite (Shanks III, 2012) typical of environments with $\mathrm{pH}$ lower than 4 and well-described in different hydrothermal ore deposits (Meyer \& Hemley, 1967). Minerals belonging to the alunite supergroup can have hypogene hydrothermal, hypogene steam-heated and supergene origin (Dill, 2001). Hypogene hydrothermal alunite is commonly enriched in $\mathrm{PO}_{4}{ }^{3-}$, and cations such as $\mathrm{Ca}^{2+}, \mathrm{Sr}^{2+}, \mathrm{Ba}^{2+}$ whereas steam-heated alunites lack a complex core and are characterized by a limited range of alunitenatroalunite solid solutions (Aoki et al., 1993). P- and Sr-content in alunite deposits reflects the source of the parent solution (accessory hydroxylapatite, monazite, xenotime, and alkali feldspar).

We discovered abundant phosphates (i.e., goyazite and leucophosphite) and solid solutions between phosphates and sulfates in Monte Cucco systems (Fig. 10A), and Corona 'e sa Craba (vashegyite, berlinite(?), taranakite), but also fluorapatite-hydroxylapatite minerals associated with gibbsite, likely related to subsequent events that induce weathering of primaryacidic deposits.

Hydroxylapatite is stable at $\mathrm{pH}$ close to 6 , whilst gibbsite (the final product of phosphate alteration) occurs at $\mathrm{pH}>5$ (Dill, 2001 and references therein). In all the studied cases, we have never observed andalusite $\left[\mathrm{Al}_{2} \mathrm{SiO}_{5}\right]$ as an alteration product; this means that the temperature never exceeded $400^{\circ} \mathrm{C}$ and the widespread presence of jarosite suggests the temperature was always below $200^{\circ} \mathrm{C}$ (Barth-Wirshing et al., 1990). In acidic sulfate waters kaolinite and gibbsite (the last products of aluminosilicate weathering) are not the most stable phases. Other minerals such as pickeringite and aluminocopiapite may form (Bigham $\&$ Nordstrom, 2000). Pickeringite and copiapite have been previously described in cave environments, and in association with tamarugite (Forti et al., 1995; 1996), in the Alum volcanic cave (Vulcano Island, Sicily) and with römerite $\left[\mathrm{Fe}^{2+} \mathrm{Fe}^{3+}{ }_{2}\left(\mathrm{SO}_{4}\right)_{4} \cdot 14 \mathrm{H}_{2} \mathrm{O}\right]$ and coquimbite $\left[\mathrm{Fe}^{3+}{ }_{2}\left(\mathrm{SO}_{4}\right)_{3} \cdot 9 \mathrm{H}_{2} \mathrm{O}\right]$ in Carlsbad Caverns (Mosch \& Polyak, 1996). Pickeringite, metavoltine, and tamarugite have been seen in the volcanic-fumarole related environment of Grotta dello Zolfo (Naples, Italy) (Franco, 1961), and more recently, with a wide variety of sulfates in the Cuve de los Minerales on Irazù Volcano, Costa Rica (Ulloa et al., 2018). Pickeringite and tamarugite have also been encountered in thermal caves such as the case of Diana in Romania (Diaconu \& Medesan, 1973; Puşcaş et al., 2013). The sources of $\mathrm{Na}^{+}$, inducing the precipitation of tamarugite and metavoltine, can be linked to the upwelling waters, whilst $\mathrm{Mg}^{2+}$ (pickeringite) to the dissolution of dolostone (Triassic Dolomia Principale): this would also explain why we found pickeringite only in the Calabrian systems.

Bellini (1901) and Lacroix (1907) firstly documented metavoltine deposits, showing them to be characterized by yellowish small rosettes with hexagonal crystals, as those found in Acqua Mintina (Fig. 7D). Hexahydrite is a stable species in caves; in fact, it has been recorded in several natural underground environments worldwide (Freeman et al., 1973; Shopov, 1990; Martini, 1993; Forti et al., 1995). We found it in association with pickeringite-copiapite-tamarugiteepsomite-tschermigite in Calabrian thermal spas and with metavoltine-epsomite in Acqua Mintina Cave. Tschermigite deposits are explained by Hill $\&$ Forti (1997) by a combined presence of pyrite, fresh bat guano, and clay minerals, which supply all the elements needed for its growth (Martini, 1983). Tschermigite has also been observed in the thermal sulfidic Serpents cave in France where it occurs together with alunogen $\left[\mathrm{Al}_{2}\left(\mathrm{SO}_{4}\right)_{3}\left(\mathrm{H}_{2} \mathrm{O}\right)_{12} \cdot 5 \mathrm{H}_{2} \mathrm{O}\right]$ and jurbanite $\left[\mathrm{Al}\left(\mathrm{SO}_{4}\right)(\mathrm{OH}) \cdot 5 \mathrm{H}_{2} \mathrm{O}\right]$ (Audra \& Hobléa, 2007). In the Calabrian thermal spas (Terme Sibarite at Cassano allo Ionio and Ninfe Cave at Cerchiara di Calabria), we also found copiapite deposits associated with gypsum, jarosite and/or pickeringite, tamarugite, hexahydrite. A feasible explanation for the presence of copiapite deposits can be linked to the partial oxidation of effluorescent Fe-sulfate minerals (melanterite $\left[\mathrm{Fe}\left(\mathrm{SO}_{4}\right) \cdot 7 \mathrm{H}_{2} \mathrm{O}\right]$, rozenite $\left[\mathrm{Fe}^{2+}\left(\mathrm{SO}_{4}\right) \cdot 4 \mathrm{H}_{2} \mathrm{O}\right]$, and szomolnokite $\left.\left[\mathrm{Fe}\left(\mathrm{SO}_{4}\right) \cdot \mathrm{H}_{2} \mathrm{O}\right]\right)$, forming when a solution, after the precipitation of soluble iron-sulfate minerals, becomes progressively more concentrated in iron (Bigham \& Nordstrom, 2000). An upwelling $\mathrm{K}$-poor and $\mathrm{Fe}^{3+}$-rich acidic fluid can deposit copiapite (Bigham \& Nordstrom, 2000).

At $\mathrm{pH}$ higher than 5 Aluminum is insoluble, and if an Al-rich solution mixes with a fluid with $\mathrm{pH}$ higher than 5, felsőbányaite will precipitate. Felsőbányaite 
(Martini,1993; Shopov, 1993; Hill \& Forti, 1997) can form because of the dissolution of Al-rich shales in sulfuric acid environments. In Corona 'e sa Craba, felsőbányaite is associated with alunite, jarosite, and halloysite $10 \AA\left[\mathrm{Al}_{2} \mathrm{Si}_{2} \mathrm{O}_{5}(\mathrm{OH})_{4} \cdot 2 \mathrm{H}_{2} \mathrm{O}\right]$, thought to have developed in sub-aerial conditions, when $\mathrm{H}_{2} \mathrm{SO}_{4}$ reacted with the host rock and $\mathrm{Al}-\mathrm{Fe}-\mathrm{Mg}$ residues were released during silicization of dolomite (Sauro et al., 2014). As a matter of fact, even after the drop of the sulfuric water table, convective $\mathrm{H}_{2} \mathrm{~S}$-rich air flow induced by the thermal gradient could encounter the $\mathrm{O}_{2}$-rich atmosphere (Ritchie, 1994) and interfere with insoluble deposits producing aluminum sulfates and silicates.

The presence of halloysite $10 \AA$ deposits in Monte Cucco caves can also be due to the alteration of smectite clays following the reaction (3); the free $\mathrm{Ca}^{2+}$ ions, together with $\mathrm{Ti}$, were able to produce titanite.

3) 6 smectite $+12 \mathrm{H}^{+}+2 \mathrm{H}_{4} \mathrm{SiO}_{4}+2 \mathrm{Al}(\mathrm{OH})_{4} \geq 12$ Halloysite $+\mathrm{Ca}^{2+}$.

Finally, greenalite $\left[\left(\mathrm{Fe}^{2+}, \mathrm{Fe}^{3+}\right)_{2-3} \mathrm{Si}_{2} \mathrm{O}_{5}(\mathrm{OH})_{4}\right]$ characterized by green to reddish colors has been found in Grotta che Parla, in Sicily, together with gypsum, calcite, and dolomite deposits. Greenalite is considered a part of the kaolinite-serpentine mineral group, and can be associated with pyrite and with "Mantos" or stratabound type ore deposits, in the mineralogical assemblage constituted by greenalite-magnetitesulfide-carbonate-silica (López-García et al., 2011). Greenalite minerals could be linked to the presence of volcanic intrusive dikes and Fe-Mn encrustations. In addition, Montagna Grande represents part of a huge thrust-belt system overlapping terrigenous deposits containing pyrite.

\section{CONCLUSIONS}

The mineralogical associations described in this paper reveal new insights into sulfuric acid speleogenesis of Italy. Cave environments are preferential sites able to yield clues, no more present at the surface because of erosion, preserving important information about the geological processes and landscape evolution. We focused on 15 cave systems showing each of them containing peculiar mineral assemblages typical of sulfuric acid speleogenesis. XRD and SEM results allowed us to understand how geomorphological features (cupolas, replacement pockets, feeders, sulfuric notches, sub-horizontal cave levels, etc.) wellfit with the observed mineralogy, suggesting sulfuric acid occurrences also for systems never studied in detail such as Cavallone-Bove, Santa Cesarea Terme, Acqua Mintina, and Grotta che Parla. Nevertheless, further investigations (i.e., stable isotopes, trace elements, dating of alunite-jarosite deposits) deserve to be done to better elucidate the condition of their genesis. Gypsum is the most common mineral, as already explained by Hill \& Forti (1997), due to its capacity to immediately replace carbonate in $\mathrm{H}_{2} \mathrm{SO}_{4}$ rich environments. Native sulfur deposits have been observed in almost all the studied systems, but they are very abundant only in a few caves such as Santa Cesarea Terme, Cala Fetente, and Acqua
Mintina, where they entirely cover walls, ceilings and speleothems. Such occurrence would suggest these systems have had important $\mathrm{H}_{2} \mathrm{~S}$ degassing during the time. A biogenic or microbially-induced precipitation of $\mathrm{S}$ should be further investigated. Of great interest are the mineralogical associations found in the Monte Cucco caves characterized by baryte-fluorite deposits, likely formed during large orogenic events (Barbieri et al., 1982; Hanor, 2000). Their subsequent interaction with $\mathrm{H}_{2} \mathrm{SO}_{4}$ allowed the formation of solid solution between baryte and celestine and alteration of fluorite in a series of minerals going from fluorapatite to gibbsite. The presence of rutile needles and spheres of titanite would testify their authigenic origin, which means that the titanium was in solution and not transported as particle by the upwelling flow. In Monte Cucco caves alunite is in assemblage with peculiar phosphates like goyazite and leucophosphite. Other relevant results have been obtained from Cavallone-Bove caves, where pure white alunite, yellowish jarosite deposits and bountiful alunite-natroalunite-jarosite solid solutions are also phosphate-rich. The abundant presence of $\mathrm{PO}_{4}^{3-}$, in the core of alunite-jarosite deposits, strongly suggests hypogene hydrothermal origin of fluids involved in the formation of aluminium phosphates and sulfates (Dill, 2001).

Corona 'e sa Craba Cave is the only hypogene system, described here, to have developed in quartzite rocks. As well explained by Sauro et al. (2014), the several stages of rising fluids have been characterized by a clear evolution of $\mathrm{pH}$, from alkaline-reductive solutions (allowing silicization of dolomite rocks, mobilization of $\mathrm{Ba}$ ions and deposition of felsőbányaite and cinnabar [HgS] minerals) to more acidic-oxidative conditions (inducing the deposition of typical sulfates and silicates such as alunite-jarosite-halloysite $10 \AA$ ).

The Buso della Pisatela-Rana (Tisato et al., 2012) and Grotta che Parla represent sulfuric acid systems that gain their acidity from the oxidation of pyrite minerals contained in the host rock, as suggested by both the lack of a peculiar suite of sulfates and the presence of greenalite, described (López-Garcia et al., 2011) in association with ore materials and pyrite.

Finally, yellowish deposits of copiapite-pickeringitetamarugite-hexahydrite have been observed above the present sulfuric water-level in Calabrian caves, whereas deposits of metavoltine (a quite rare SAS mineral) occur in the entrance hall of Acqua Mintina Cave, demonstrating $\mathrm{H}_{2} \mathrm{SO}_{4}$ degassing to produce a peculiar sulfuric acid association of minerals, already documented in other famous SAS system around the world.

\section{ACKNOWLEDGEMENTS}

We thank all the people that helped us during all the field activities to collect these interesting sulfuric acid minerals, including Angelo Moschetta for the access to Cavallone-Bove caves, Giuseppe Antonini for useful discussions and help during field campaigns, and for the photographic documentation of Cavallone-Bove caves, Jennifer Macalady and Maurizio Maniero. 
Luca Poderini during our tours to the La Grotta and Faggeto Tondo caves in Monte Cucco. Peppino Martire, Carlo Forace, and all the cavers of the Speleological group Liocorno that helped us in having contact with Terme Sibarite spa and to visit Cassano allo Ionio Caves, Antonio Cesarini and the caver group "Serra del Gufo". The Management of Porretta Terme Spa and Terme di Santa Cesarea are thanked for allowing entering in the caves, Sergio Pistico for its availability during the uncountable periods of sampling. We thank Pietro Valenti, Philippe Audra, Didier Cailhol, Marjan Temovski, Jean-Yves Bigot that joined us during the mineralogical sampling occurred in the Sicilian caves, and Francesco Sauro for the scientific expedition in Monte Cucco.

Tommaso Balduccio and the Management of "Gecoin" quarry for the great willingness to carry out the investigations in the Grotta che Parla Cave, cavers from ANS "Le Taddarite" of Palermo for the support in field activities. The access to Grotta dell'Acqua Mintina was possible thanks to Giovanni Stuppia and Rosario Ruggieri. Ilenia D’Angeli thanks Penelope Boston and Mike Spilde for the suggestions and discussions on cave geology and mineralogy during the period spent in Albuquerque.

\section{REFERENCES}

Angiboust S. \& Harlov D., 2017 - Ilmenite breakdown and rutile-titanite stability in metagranitoids: natural observations and experiment results. Journal of Earth and Planetary Materials, 102 (8): 1696-1708.

https://doi.org/10.2138/am-2017-6064

Aoki M., Comsti E.C. \& Lazo F.B., 1993 - Advanced argillic alteration and geochemistry of alunite in an evolving hydrothermal system at Baguio, Northern Luzon, Philippines. Resource Geology, 43: 155-164.

Audra P., 2007 - Karst et spéléogenèse épigènes, hypogènes, recherches appliquées et valorisation (Habilitation Thesis). University of Nice SophiaAntipolis, $278 \mathrm{p}$.

Audra P., 2008 - Hypogenic sulfidic speleogenesis. Berliner Höhlenkundliche Berichte, 26: 15-32.

Audra P. \& Hobléa F., 2007 - The first cave occurrence of Jurbanite $\left[\mathrm{Al}\left(\mathrm{OH} \mathrm{SO}_{4}\right) \cdot 5 \mathrm{H}_{2} \mathrm{O}\right]$, associated with alunogen $\left[\mathrm{Al}_{2}\left(\mathrm{SO}_{4}\right)_{3} \cdot 17 \mathrm{H}_{2} \mathrm{O}\right]$ and Tschermigite $\left[\mathrm{Al}_{2}\left(\mathrm{SO}_{4}\right)_{2} \cdot 12 \mathrm{H}_{2} \mathrm{O}\right]$ : thermal sulfidic serpents cave, France. Journal of Cave and Karst studies, 69 (2): 243-249.

http://ww.caves.org/pub/journal/PDF/v69/cave-6902-243.pdf

Audra P., Gázquez F., Rull F., Bigot J.Y. \& Camus H., 2015 - Hypogene Sulfuric Acid Speleogenesis and rare sulfate minerals in Baume Galinière Cave (Alpes-de-HauteProvence, France). Record of uplift, correlative cover retreat and valley dissection. Geomorphology, 247: 2534. https://doi.org/10.1016/j.geomorph.2015.03.031

Azzaroli A., 1967 - Calcare di Altamura. Note illustrative della Carta Geologica d'Italia. Formazioni Geologiche, 1: 151-156.

Barbieri M., Masi U. \& Tolomeo L., 1982 - Strontium geochemistry in the epithermal barite deposits from the Apuan Alps (Northern Tuscany, Italy). Chemical Geology, 35: 351-356.

https://doi.org/10.1016/0009-2541(82)90011-0

Barth-Wirsching U., Ehn R., Höller H., Klammer D. \& Sitte W., 1990 - Studies of hydrothermal alteration by acid solution dominated by $\mathrm{SO}_{4}^{2-}$ : formation of the alteration products of the Gleichenberg latitic rock (Styria, Austria). Experimental evidence. Mineralogy and Petrology, 41: 81-103. https://doi.org/10.1007/BF01168489

Basilone L., 2012 - Unità carbonatiche MesozoicoPaleogeniche. Litostratigrafia delle Sicilia, 24-64.

Bellini R., 1901 - La Grotta dello Zolfo nei Campi Flegrei. Bollettino della Società Geologica Italiana, 20: 470-475.

Bertolani M., Garuti G., Rossi A. \& Bertolani Marchetti D., 1976 - Motivi di interesse mineralogico-petrografico nel complesso carsico Grotta Grande del Vento-Grotta del Fiume (Genga, Ancona). Le Grotte d'Italia, IV (6): 109-144.

Bigham J.M. \& Nordstrom D.K., 2000 - Iron and Aluminium Hydroxysulfates from acid sulfate waters. Reviews in Mineralogy and Geochemistry, 40: 351-403. https://doi.org/10.2138/rmg.2000.40.7

Buck M.J., Ford D.C. \& Schwarcz H.P., 1994 Classification of cave gypsum deposits derived from oxidation of $\mathrm{H}_{2} \mathrm{~S}$. In: Sasowsky I. \& Palmer M.V. (Eds.), Breakthroughs in karst geomicrobiology and redox geochemistry. Karst Water Institute, Special Publication, 1: 5-9.

Callière S. \& Hénin S., 1963 - Minéralogie des argiles. Masson et C.ie (Ed.), Paris, 356 p.

Canfield D.E., 2001 - Biogechemistry of sulfur isotopes. Reviews in Mineralogy and Geochemistry, 43: 607-636.

Canganella F., Bianconi G., Kato C. \& Gonzales J., 2007 - Microbial ecology of submerged marine caves and holes characterised by high levels of hydrogen sulphide. Review in Environmental Science and Bio/Technology, 6: 61-70. http://doi.org/10.1007/s11157-006-9103-2

Carbone C., Dinelli E., Marescotti P., Gasparotto G. \& Lucchetti G., 2013 - The role of AMD secondary minerals in controlling environmental pollution: indications from bulk leaching tests. Journal of Geochemical Exploration 132: 188-200.

https://doi.org/10.1016/j.gexplo.2013.07.001

Carswell D.A. \& O’Brien P.J., 1993 - Thermobarometry and geotectonic significance of high-pressure granulites: examples from the Moldanubian Zone of the Bohemian Massif in Lower Austria. Journal of Petrology, 34 (3): 427-459. https://doi.org/10.1093/petrology/34.3.427

Catalano R., Agate M., Albanese C., Avellone G., Basilone L., Gasparo M., Gugliotta C., Sulli A., Valenti V., Gibilaro C. \& Pierini S., 2013 - Walking along a crustal profile across the Sicily fold and thrust belt. American Association of Petroleum Geologists. Post Conference Field Trip 4, Palermo. Geological field trips, 5 (2-3): $213 \mathrm{p}$.

Catalano M., Bloise A., Miriello D., Apollaro C., Critelli T., Muto F., Cazzanelli E. \& Barrese E., 2014 - The mineralogical study of the Grotta Inferiore di Sant'Angelo (southern Italy). Journal of Cave and Karst Studies, 76 (1): 51-61. https://doi.org/10.4311/2012ES0284

Ciarapica G., Cirilli S., Passeri L., Trincardi E., Zaninetti L., 1986 - "Anidriti di Burano" et "Formation du Monte Cetona" (nouvelle formation), biostratigraphie de duex series-types du Trias supérieur dans l'Apennin septentrional. Revue de Paléobiologie, 6 (2): 341-409.

Cucchi F. \& Forti P., 1988 - Speleogenetic evolution of Fiume-Vento karst system (San Vittore Genga-Marche). International Symposium of Physics, Chemistry and Hydrology Reservoir of Karst, Kosice, p. 193-199.

D’Angeli I.M., De Waele J., Galdenzi S., Madonia G., Parise M., Piccini L. \& Vattano M., 2016 - Sulfuric acid caves of Italy: an Overview. In: Chavez T. \& Reehling P. (Eds.), NCKRI Symposium 6, Proceedings of DeepKarst 2016: Origins, Resources, and Management of Hypogene Karst. Carlsbad, New Mexico, p. 85-88. 
D’Angeli I.M., Vattano M., Parise M. \& De Waele J., 2017 a - The coastal sulfuric acid cave system of Santa Cesarea Terme (southern Italy). In: Klimchouk A.B., Palmer A.N., De Waele J., Auler A. \& Audra P. (Eds.), Hypogene karst regions and caves of the world. Springer, Cham, p. 161-168. http://doi.org/10.1007/978-3-319-53348-3

D’Angeli I.M., De Waele J., Ieva M.G., Leuko S., Cappelletti M., Parise M., Jurado V., Miller A.Z. \& SaizJimenez C., 2017b - Next-Generation Sequencing for microbial characterization of biovermicuations from a sulfuric acid cave in Apulia (Italy). Proceedings of the $17^{\text {th }}$ International Congress of Speleology, Sydney, p. 377-380.

Davis D.G., 2000 - Extraordinary features of Lechuguilla cave, Guadalupe Mountains, New Mexico. Journal of Cave and Karst Studies, 62 (2): 147-157.

De Waele J., Galdenzi S., Madonia G., Menichetti M., Parise M., Piccini L., Sanna S., Sauro F., Tognini P., Vattano M. \& Vigna B., 2014 - A review on hypogene caves in Italy. In: Klimchouk A.B., Sasowsky I., Myrloie J., Engel S., Summers Engel A. (Eds.), Hypogene cave morphologies. Karst Water Institute, Special Publication, 18: 28-30.

De Waele J., Audra P., Madonia G., Vattano M., Plan L., D’Angeli I.M., Bigot J.-Y. \& Nobécourt J.-C., 2016 - Sulfuric acid speleogenesis (SAS) close to the water table: examples from southern France, Austria, and Sicily. Geomorphology, 253: 452-467.

http://doi.org/10.1016/j.geomorph.2015.10.19

Dill H.G., 2001 - The geology of aluminium phosphates and sulphates of alunite group minerals: a review. Earth-Science Reviews, 53: 35-93. https://doi.org/10.1016/S0012-8252(00)00035-0

Diaconu G., Medesan A., 1973 - Sur la presence $d u$ pickeringite dans la grotte Diana [Băile Herculane Roumanie]. Travaux de l'Institut de Spéleologie "Emile Racovitza", 14: 149-156.

Doglioni C. \& Flores G., 1997 - An introduction to the Italian geology. Lamisco, Potenza, 98 p.

Dutrizac J.E. \& Jambor J.L., 2000 - Jarosite and their application in hydrometallurgy. Reviews in Mineralogy and Geochemistry, 40: 405-452.

https://doi.org/10.2138/rmg.2000.40.8

Egemeier S.J., 1981 - Cavern development by thermal waters. National Speleological Society Bulletin, 43: 31-51.

Fabiani R., 1915 - Il paleogene del Veneto. Memorie dell'Istituto di Geologia della Regia Università di Padova, 3: 1-336.

Forti P. \& Mocchiutti A., 2004 - Le condizioni ambientali che permettono l'evoluzione di speleotemi di zolfo in cavità ipogeniche: nuovi dati dalle grotte di Capo Palinuro (Salerno, Italia). Le Grotte d'Italia, v (4): 39-48.

Forti P., Menichetti M. \& Rossi A., 1989 - Speleothems and speleogenesis of the Faggeto Tondo cave (UmbriaItaly). Proceedings of the $10^{\text {th }}$ International Speleological Congress, Budapest, 1: 74-76.

Forti P., Panzica La Manna M., Rossi A., 1995 - Il particolare ambiente della Grotta dell'Allume (Vulcano, Sicilia). Atti del secondo Convegno Regionale di Speleologia, Catania, 37: 251-272.

Forti P., Panzica La Manna M., Rossi A., 1996 - The peculiar mineralogic site of the Alumn Cave (Vulcano, Sicily). $7^{\circ}$ International Symposium Vulcanospeleological, Canary Islands, p. 15-17.

Franco E., 1961 - Su alcuni minerali della Grotta dello Zolfo (Miseno). Bollettino della Società dei Naturalisti Napoli, 70: 156-160.
Freeman J.P., Smith G.P., Poulson T.L., Watson P.J. $\&$ White W.B., 1973 - Lee Cave, Mammoth Cave National Park, Kentucky. National Speleological Society Bullettin, 35 (4): 109-126.

Galdenzi S., 1990 - Un modello genetico per la Grotta Grande del Vento. Memorie dell'Istituto Italiano di Speleologia, II (4): 123-142.

Galdenzi S., 2001 - L'azione morfogenica delle acque sulfuree nelle grotte di Frasassi, Acquasanta Terme (appennino-Umbro-Marchigiano, Italia) e di Movile (Dobrogea, Romania). Le Grotte d'Italia, v (2): 49-61.

Galdenzi S. \& Menichetti M., 1995 - Occurrence of hypogene caves in a karst region: example from central Italy. Environmental Geology, 26: 39-47. https://doi.org/10.1007/BF00776030

Galdenzi S., Cocchioni F., Filipponi G., Selvaggio R., Scuri S., Morichetti L. \& Cocchioni M., 2010. The sulfidic thermal caves of Acquasanta Terme (central Italy). Journal of Cave and Karst Studies, 72 (1): 43-58.

https://doi.org/10.4311/jcks2008es0056

Goldbery R., 1980 - Early diagenetic, Na-alunites in Miocene algal mat intertidal facies, Ras Sudar, Sinai. Sedimentology, 27: 189-198.

https://doi.org/10.1111/j.1365-3091.1980.tb01169.x

Gross G.A., 1983 - Tectonic systems and the deposition of iron-formation. Precambrian Research, 20: 171-187. https://doi.org/10.1016/0301-9268(83)90072-4

Hanor J.S., 2000 - Barite-Celestine geochemistry and environment of formation. Reviews in Mineralogy and Geochemistry, 40: 193-275. https://doi.org/10.2138/rmg.2000.40.4

Henry D.J. \& Guidotti C.V., 2002 - Titanium in biotite from metapelitic rocks: temperature effects, crystalchemical controls, and petrologic application. American Mineralogist, 87: 375-382. https://doi.org/10.2138/am-2002-0401

Hill C.A., 1981 - Celestine growing in Floyd Collins Crystal Cave. Cave Researches Foundation, Annual Report, 23: 9.

Hill C.A., 1987 - Celestine in Carlsbad Caverns. Cave Researches Foundation, Annual Report, 29: 15.

Hill C.A., 1990 - Sulfuric acid speleogenesis of Carlsbad Cavern and its relationship to hydrocarbons, Delaware Basin, New Mexico and Texas. American Association of Petroleum Geologists Bullettin, 74: 1685-1694.

Hill C.A., 1992 - Isotopic values of native sulfur, barite, celestite, and calcite: their relationship to sulfur deposits and to the evolution of the Delaware basin (preliminary results). In: Wessell G.R. \& Wimberly B.H. (Eds.), Native sulfur-development in geology and exploration. Phoenix, AZ: Society of Mining, Metallurgy and Exploration, p. $147-157$.

Hill C.A., 1995 - Sulfur redox reactions: hydrocarbon, native sulfur, Mississippi Valley-type deposits, and sulfuric acid karst in the Delaware Basin, New Mexico and Texas. Environmental Geology, 25: 16-23. https://doi.org/10.1007/BF01061826

Hill C.A. \& Forti P., 1997 - Cave minerals of the world ( $2^{\text {nd }}$ Ed.). National Speleological Society, Huntsville, AL, $463 \mathrm{p}$.

Hose L.D., Palmer A.N., Palmer M.V., Northup D.E., Boston P.J. \& DuChene H.R., 2000 - Microbiology and geochemistry in hydrogen-sulfide-rich karst environment. Chemical Geology, 169: 399-423. https://doi.org/10.1016/S0009-2541(00)00217-5

Imhoff J.F., 2006 - The Chromatiaceae. Prokaryotes, 6: 846-873. https://doi.org/10.1007/0-387-30746-x_31

Jagnow D.H., Hill C.A., Davis D.G., DuChene H.R., Cunningham K.I., Northup D.E. \& Queen J.M., 2000 - History of the sulfuric acid theory of speleogenesis in 
the Guadalupe Mountains, New Mexico. Journal of Cave and Karst Studies, 62 (2): 54-59.

http://ww.caves.org/pub/journal/PDF/V62/v62n2Jagnow.pdf

Klimchouk A.B., 2005-Conceptualization of speleogenesis in multy-storey artesian systems: a model of transverse spelegenesis. International Journal of Speleology, 34 (1-2): 45-64.

https://doi.org/10.5038/1827-806X.34.1.4

Klimchouk A.B., 2007 - Hypogene speleogenesis: hydrogeological and morphogenetic perspective. National Cave and Karst Research Institute, Special Paper 1, Carlsbad.

Klimchouk A.B., 2009 - Morphogenesis of hypogenic caves. Geomorphology, 106: 100-117. https://doi.org/10.1016/j.geomorph.2008.09.013

Klimchouk A.B., 2017 - Types and settings of hypogene karst. In: Klimchouk A.B., Palmer A.N., De Waele J., Auler A. \& Audra P. (Eds.), Hypogene karst regions and caves of the world. Springer, Cham, p. 1-39. https://doi.org/10.1007/978-3-319-53348-3_1

Klimchouk A.B., Auler A., Bezerra F.H.R., Cazarin C.L., Balsamo F. \& Dublyansky Y., 2016 - Hypogenic origin, geologic controls and functional organization of a giant cave system in Precambrian carbonates, Brazil. Geomorphology, 253: 385-405.

https://doi.org/10.1016/j.geomorph.2015.11.002

Kulp E.A., Kothari H.M., Limmer S.J., Yang J., Gudavarthy R.V., Bohannan E.W. \& Switzer J.A., 2009 - Electrodeposition of epitaxal magnetite films and ferrihydrite nanoribbons on single-crystal gold. Chemistry Materials, 21 (21): 5022-5031.

https://doi.org/10.1021/cm9013514

Lacroix A., 1907 - Sur deux gisements nouveaux de metavoltine. Bulletin Française de Minéralogie et de Cristallographie, 30: 30.

López-García J.A., Oyarzun R., López Andrés S. \& Manteca Martinez J.I., 2011 - Scientific, educational, and environmental considerations regarding mine sites and geoheritage: A perspective from SE Spain. Geoheritage, 3 (4): 267-275.

https://doi.org/10.1007/s12371-011-0040-2

Lugli S., Ruggieri R., Orsini R. \& Sammito G., 2016 Grotta dell'Acqua Mintina, a peculiar geosite with the smell of sulfur. Proceeding of the $4^{\text {th }}$ International Symposium on karst in the South Mediterranean area. Karst Geosites, p. 65-71.

Macalady J.L., Lyon E.H., Koffman B., Albertson L.K., Meyer K., Galdenzi S. \& Mariani S., 2006 Dominant microbial population in limestone-corroding stream biofilms, Frasassi cave system, Italy. Applied Environmental Microbiology, 72 (8): 5596-5609.

https://doi.org/10.1128/AEM.00715-06

Machel H., 2001 - Bacterial and thermochemical sulfates reduction in diagenetic settings - old and new insights. Sedimentary Geology, 140: 143-175.

https://doi.org/10.1016/S0037-0738(00)00176-7

Mansor M., Harouaka K., Gonzales M.S., Macalady J.L. \& Fantle M.S., 2018 - Transport-induced spatial patterns of sulfur isotopes $\left(\delta^{34} S\right)$ as biosignature. Astrobiology, 18 (1): 1-14. https://doi.org/10.1089/ast.2017.1650

Manzi V., Lugli S., Roveri M. \& Schreiber B.C., 2009 - A new facies model for the Upper Gypsum (Sicily, Italy): chronological and paleoenvironmental constraints for the Messinian salinity crisis in the Mediterranean. Sedimentology, 56: 1937-1960.

https://doi.org/10.1111/j.1365-3091.2009.01063.x

Martini J.E., 1983 - Lonecreenite, sabietite, and clairite, a new secondary ammonium ferric-iron sulphate from
Lone Creek Fall Cave, near Sabie, eastern Transvaal. Bullettin Geological Survey of South Africa, 17: 29-34.

Martini J.E., 1993 - A concise review of the cave mineralogy of Southern Africa. Proceeding $11^{\text {th }}$ International Speleological Congress, Beijing, p. 72-75.

Martinis B. \& Pieri M., 1964 - Alcune notizie sulla formazione evaporitica del Triassico superiore nell'Italia centrale e meridionale. Memorie della Società Geologica Italiana, 4 (1): 649-678.

Martire L., Pavia G., Pochettino M. \& Cecca F., 2000 - The Middle-Upper Jurassic of Montagna Grande (Trapani): Age, Facies, and Depositional Geometries. Memorie della Società Geologica Italiana, 55: 219-225.

Menichetti M., 2008 - Assetto strutturale del sistema geotermico di Acquasanta Terme (Ascoli Piceno). Rendiconti online della Società Geologica Italiana, 1: $118-122$.

Meyer C. \& Hemley J.J., 1967 - Wall rock alteration. In: Barnes H.L. (Ed.), Geochemistry of hydrothermal ore deposits. John Wiley \& Sons, Hoboken, p. 166-235.

Millot G., 1964 - Géologie des argiles. Masson at C.ie (Ed.), Paris, 499 p.

Minissale A., 2004 - Origin, transport and discharge of $\mathrm{CO}_{2}$ in central Italy. Earth-Science Reviews, 66: 89-141. https://doi.org/10.1016/j.earscirev.2003.09.001

Mosch C. \& Polyak V.J., 1996 - Canary yellow-cave precipitates: late stages of hydrated uranyl-vanadate, uranyl silicate, and iron sulfate minerals (abs.). National Speleological Society, Salida, Colorado, August 5-9, p. 51.

Onac B.P. \& Forti P., 2011 - Minerogenic mechanisms occurring in the cave environment: an overview. International Journal of Speleology, 40 (2): 79-98. https://doi.org/10.5038/1827-806X.40.2.1

Onac B.P., Sumrall J., Tămaş T., Povară I., Kearns J., Dârmiceanu V., Veres D. \& Lascu C., 2009 - The relationship between cave minerals and $\mathrm{H}_{2} \mathrm{~S}$-rich thermal waters along the Cerna Valley (SW Romania). Acta Carsologica, 38 (1): 27-39. https://doi.org/10.3986/ac.v38i1.135

Onac,B.P., Wynn J.G. \& Sumrall J.B., 2011 - Tracing the sources of cave sulfates: a unique case from Cerna Valley, Romania. Chemical Geology, 288 (3-4): 105-114. https://doi.org/10.1016/j.chemgeo.2011.07.006

Padalino G., Pretti S., Tamburrini D., Tocco S., Uras I., Violo M. \& Zuffardi P., 1973 - Ore deposition in karst formations with examples from Sardinia. In: Amstutz G.C. \& Bernard C. (Eds.), Ores in sediments. Springer Verlag, Berlin, p. 209-220.

https://doi.org/10.1007/978-3-642-65329-2_16

Palmer A.N., 2007 - Cave geology. Cave Books, Dayton, 454 p.

Palmer A.N., 2011 - Distinction between epigenic and hypogenic maze caves. Geomorphology, 134: 9-22. https://doi.org/10.1016/j.geomorph.2011.03.014

Palmer A.N., 2013 - Sulfuric acid caves: Morphology and Evolution. In: Frumkin A., Shroder J. (Eds.), Treatise on geomorphology. Elsevier, Berlin, p. 241-257.

Palmer A.N. \& Palmer M.V., 1992 - Geochemical and petrological observations in Lechuguilla cave, New Mexico (abs.). In: Ogden A.E. (Ed.), Friends of karst meeting. Proceedings of the Tennessee Tech University, Cooksville, Tennessee, p. 25-26.

Palmer A.N. \& Palmer M.V., 2000 - Hydrochemical interpretation of cave patterns in the Guadalupe Mountains, New Mexico. Journal of Cave and Karst Studies, 62 (2): 91-108.

http://ww.caves.org/pub/journal/PDF/V62/v62n2Palmer.pdf

Perna G., 1973 - Fenomeni carsici e giacimenti minerari. Le Grotte d'Italia, IV (3): 5-44. 
Pialli G., Barchi M. \& Minelli G., 1998 - Results of the CROP 03 deep seismic reflection profile. Memorie della Società Geologica Italiana, 57: 1-657.

Piccini L., De Waele J., Galli E., Polyak V.J., Bernasconi S.M \& Asmerom Y., 2015 - Sulfuric acid speleogenesis and landscape evolution: Montecchio cave, Albegna river valley (southern Tuscany, Italy). Geomorphology, 229: 134-143.

https://doi.org/10.1016/j.geomorph.2014.10.006

Plan L., Tschegg C., De Waele J. \& Spötl C., 2012 Corrosion morphology and cave wall alteration in Alpine sulfuric acid cave (Kraushöhle, Austria). Geomorphology, 169 (170): 45-54.

https://doi.org/10.1016/j.geomorph.2012.04.006

Polyak V.J. \& Güven N., 2000 - Clay in the caves of Guadalupe Mountains, New Mexico. Journal of Cave and Karst Studies, 62 (2): 120-126.

http://ww.caves.org/pub/journal/PDF/V62/v62n2Polyak-Guven.pdf

Polyak V.J. \& Provencio P., 2001 - By-product materials related to $\mathrm{H}_{2} \mathrm{~S}-\mathrm{H}_{2} \mathrm{SO}_{4}$ influenced speleogenesisi of Carlsbad, Lechuguilla, and other caves of the Guadalupe Mountains, New Mexico. Journal of Cave and Karst Studies, 63 (1): 23-32.

http://ww.caves.org/pub/journal/PDF/V63/v63n1Polyak.pdf

Polyak V.J., McIntosh W.C., Güven N. \& Provencio P., 1998 - Age and origin of Carlsbad Caverns and related caves from ${ }^{40} \mathrm{Ar} /{ }^{39} \mathrm{Ar}$ of alunite. Science, 279: 1919-1922. https://doi.org/10.1126/science.279.5358.1919

Puşcaş C.M., Onac B.P., Effenberger H.S. \& Povara I., 2013 - Tamarugite-bearing paragenesis formed by sulphate acid alteration in Diana cave, Romania. European Journal of Mineralogy, 25 (3): 479-486. https://doi.org/10.1127/0935-1221/2013/0025-2294

Ritchie A.I.M., 1994 - The waste rock environment. In: Jambor J.L. \& Blowes D.W. (Eds), The environmental geochemistry of sulfide mine-wastes. Mineral Association Canada Short Course, 22: 131-161.

Rogers W.B., 1988 - Noncarbonate minerals in California caves (abs.). National Speleological Society Conference, Hot Spring (South Dakota), p. 1-4.

Rye R.O., Bethke P.M., Lanphere M.A. \& Steven T.A., 1993 - Age and stable isotope systematics of supergene alunite and jarosite from the Creede mining district, Colorado: implications for supergene processes and Neogene geomorphic evolution and climate of the southern Rocky Mountains (abs). Geological Society of America Abstract with programs 25, A-274.

Sarbu S.M., Kinkle B.K., Vlasceanu L., Kane T.C. \& Popa R., 1994 - Microbiological characterization of a sulfiderich groundwater ecosystem. Geomicrobiological Journal, 12: 175-182.

https://doi.org/10.1080/01490459409377984

Sauro F., De Waele J., Onac B.P., Galli E., Dublyansky Y., Baldoni E. \& Sanna L., 2014 - Hypogenic speleogenesis in quartize: the case of Corona 'e sa Craba cave (SW Sardinia, Italy). Geomorphology, 211: 77-88. https://doi.org/10.1016/j.geomorph.2013.12.031

Selli R., 1957 - Sulla trasgressione del Miocene dell'Italia meridionale. Giornale di Geologia, 26: 1-54.

Selli R., 1962 - Il Paleogene nel quadro della geologia dell'Italia centro-meridionale. Memorie della Società Geologica Italiana, 3: 737-789.

Shanks III W.C.P., 2012 - Hydrothemal alteration in volcanogenic massive sulfide occurrence model. U.S. Geological Survey Scientific Investigations Report, 11: $12 \mathrm{p}$.
Shopov Y.Y., 1990 - Development of Bulgarian Cave mineralogy (1923-1986). Bulgarian Speleology, 2: 2132 (In Bulgarian).

Shopov Y.Y., 1993 - Genetic classification of cave minerals. Proceedings $11^{\text {th }}$ International Congress of Speleology, Beijing (1993-1994), p. 101-105.

Stoffregen R.E., 1993 - Stability relations of jarosite and natroalunite at $100-250^{\circ} \mathrm{C}$. Geochimica et Cosmochimica Acta, 58: 903-916.

https://doi.org/10.1016/0016-7037(94)90514-2

Stoffregen R.E., Alpers C.N. \& Jambor J.L., 2000 Alunite-jarosite crystallography, thermodynamics, and geochronology. Reviews in Mineralogy and Geochemistry, 40: 453-479. https://doi.org/10.2138/rmg.2000.40.9

Stüben D., Sedwick P. \& Colantoni P., 1996 - Geochemistry of submarine warm springs in the limestone cavern of Grotta Azzurra, Capo Palinuro, Italy: evidence for mixingzone dolomitisation. Chemical Geology, 131: 113-125. https://doi.org/10.1016/0009-2541(96)00029-0

Stumm W., 1992 - Chemistry of the solid-water interface: Process at the mineral-water and particle-water interface in natural system. John Wiley, New York, 428 p.

Summers Engel A., Stern L.A. \& Bennett P.C., 2004 Microbial contributions to cave formation: new insights into sulphuric acid speleogenesis. Geology, 32 (5): 369372. https://doi.org/10.1130/G20288.1

Taddeucci A., Tuccimei P. \& Voltaggio M., 1992 - Studio geocronologico del complesso carsico "Grotta del FiumeGrotta Grande del Vento" (Gola di Frasassi, AN) e indicazioni paleoambientali. Il Quaternario, 5: 213-222.

Tisato N., Sauro C., Bernasconi S.M., Bruijn R.H.C. \& De Waele J., 2012 - Hypogene contribution to speleogenesis in a predominant epigenic karst system: a case study from the Venetian Alps, Italy. Geomorphology, 151152: $156-163$.

https://doi.org/10.1016/j.geomorph.2012.01.025

Tombácz E., Dobos Á., Szekeres M., Narres H.D., Klumpp E. \& Dékány I., 2000 - Effect of $p H$ and ionic strength on the interaction of humic acid with aluminium oxide. Colloid and Polymer Science, 278 (4): 337-345.

https://doi.org/10.1007/s003960050522

Tracy R.J. \& Robinson P., 1988 - Silicate-sulfideoxide fluid reactions in granulite politic rocks, central Massachusetts. American Journal of Science, 288: 45-74.

Ulloa A., Gázquez F., Sanz-Arranz A., Medina J., Rull F., Calaforra J.M., Alvarado G.E., Martinez M., Avard G., de Moor J.M. \& De Waele J., 2018 - Extremely high diversity of sulfate minerals in caves of the Irazú Volcano (Costa Rica) related to crater lake and fumarolic activity. International Journal of Speleology, 47 (2): 229-246. https://doi.org/10.5038/1827-806X.47.2.2198

Vattano M., Madonia G., Audra P., D’Angeli I.M., Galli E., Bigot J.-Y., Nobécourt J.-C. \& De Waele J., 2017 - An overview of the hypogene caves of Sicily. In: Klimchouk A.B., Palmer A.N., De Waele J., Auler A. \& Audra P., (Eds.), Hypogene karst regions and caves of the world. Springer, Cham, p. 199-210.

https://doi.org/10.1007/978-3-319-53348-3 12

Westerhoff P., Song G., Hristovski K. \& Kiser M.A., 2011 - Occurrence and removal of titanium at full scale wastewater treatment plants: implications for $\mathrm{TiO}_{2}$ nanomaterials. Journal of Environmental Monitoring, 13: 1195-1203.

https://doi.org/10.1039/c1em10017c

Williams-Jones A.E., Samson I.M. \& Olivo G.R., 2000 - The genesis of hydrothermal fluorite-REE deposits in Gallinas Mountains, New Mexico. Economic Geology, 95 (2): 327-341.

https://doi.org/10.2113/gsecongeo.95.2.327 
Wray R.A.L., 2011 - Alunite formation within silica stalactites from the Sydney Region, South-eastern Australia. International Journal of Speleology, 40 (2): 109-116. https://doi.org/10.5038/1827-806X.40.2.3
Wright G.F., 1898 - A recently discovered cave of Celestine crystals at Put-in-Bay, Ohio. Science, 8: 502-503. 